EUROPEAN CENTRAL BANK

WORKING PAPER SERIES

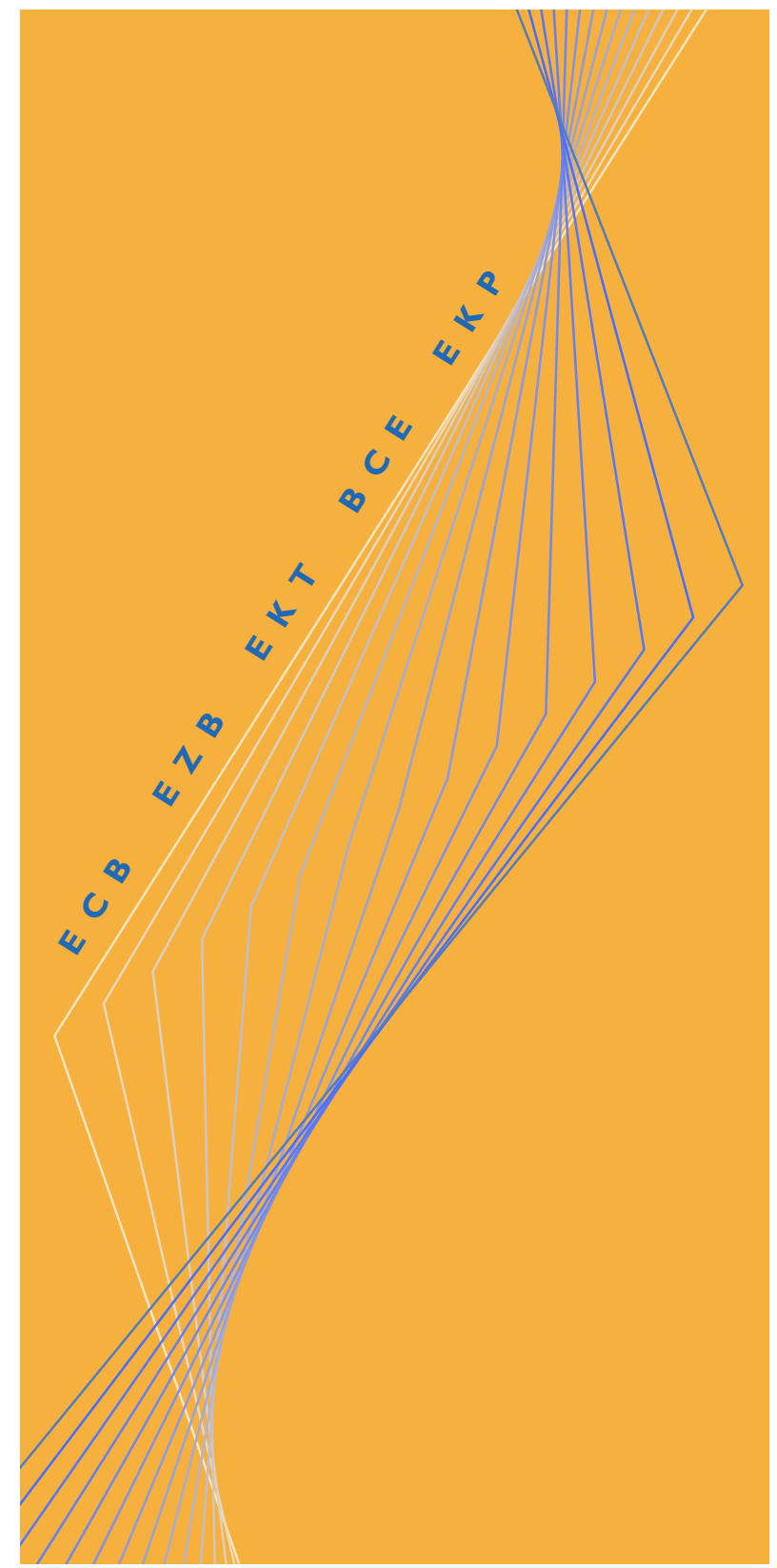

WORKING PAPER NO. 73

INTERBANK LENDING AND

MONETARY POLICY TRANSMISSION:

EVIDENCE FOR GERMANY

BY MICHAEL EHRMANN

AND ANDREAS WORMS

July 200 I 
E U R P E A N C E N T A L B A N K

WORKING PAPER SERIES

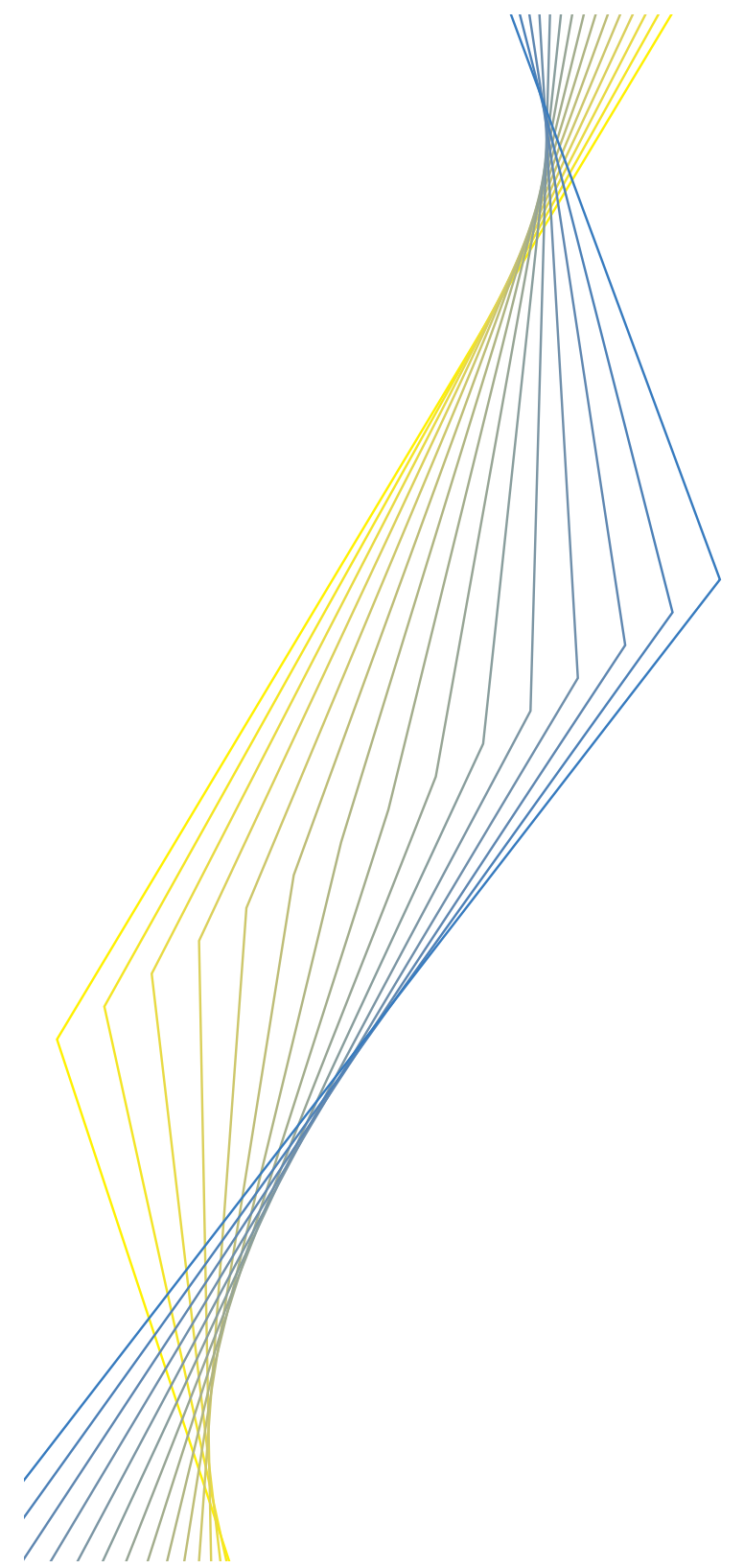

WORKING PAPER NO. 73

INTERBANK LENDING AND

MONETARY POLICY TRANSMISSION:

EVIDENCE FOR GERMANY

BY MICHAEL EHRMANN*

AND ANDREAS WORMS**

July 200 I

* European Central Bank, michael.ehrmann@ecb.int***

** Deutsche Bundesbank, andreas.worms@bundesbank.de***

** This paper represents the authors' personal opinions and does not necessarily reflect the views of the institutions they are affiliated to. We would like to thank an anonymous referee, Hans Bauer, Heinz Herrmann, Michael Scharnagl, Christian Upper and RafWouters for comments on earlier drafts, seminar participants of the Bundesbank, CFS and the ECB for further suggestions, and Anders Warne and Henrik Hansen for sharing their computer code. 
(C) European Central Bank, 200I

Address

Postal addres
Telephone
Internet
Fax
Telex

\section{Kaiserstrasse 29}

D-603 I I Frankfurt am Main

\section{Germany}

Postfach 160319

D-60066 Frankfurt am Main

\section{Germany}

$+496913440$

http://www.ecb.int

$+496913446000$

4 I I I44 ecb d

All rights reserved.

Reproduction for educational and non-commercial purposes is permitted provided that the source is acknowledged.

The views expressed in this paper are those of the authors and do not necessarily reflect those of the European Central Bank.

ISSN $1561-0810$ 


\section{Contents}

$\begin{array}{lr}\text { Abstract } & 4\end{array}$

$\begin{array}{lr}\text { Non-technical summary } & 5\end{array}$

I Introduction $\quad 6$

2 The database and the structure of the German interbank market 9

3 Definition of bank size classes and construction of grouped data $\quad 12$

3.I Descriptive evidence on the size structure of the German banking system 12

$\begin{array}{ll}3.2 \text { Construction of grouped time series } & 14\end{array}$

4 Monetary policy and bank loans to non-banks $\quad$ I5

$5 \quad$ Monetary policy and interbank lending $\quad 19$

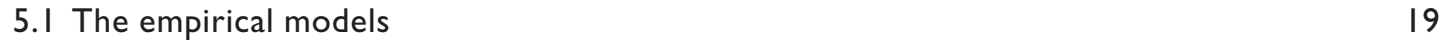

$\begin{array}{ll}5.2 \text { Segments of the interbank market } & 21\end{array}$

$\begin{array}{ll}5.3 \text { The maturity structure in the interbank market } & 23\end{array}$

$\begin{array}{ll}5.4 \text { The reaction of internal interbank market positions } & 24\end{array}$

6 Loans from banks without intra-sectoral links 25

$\begin{array}{llr}7 & \text { Conclusions } & 26\end{array}$

$\begin{array}{lr}\text { Bibliography } & 28\end{array}$

$\begin{array}{lr}\text { Appendix } & 30\end{array}$ 


\begin{abstract}
This paper presents empirical evidence on the behaviour of interbank lending in Germany after a monetary policy impulse. Our VAR analysis shows that following a monetary contraction, the banking system as a whole attracts additional funds from foreign banks. Whereas small cooperative and savings banks do not seem to directly access the interbank market themselves, they do so indirectly through the head institutions of their sectors, i.e. the savings banks' and credit cooperative sector, respectively. The interbank flows within these two sectors allow small banks to access funds that might help them in keeping their loan portfolio relatively unaffected. This may explain why the evidence for a bank lending channel in Germany seems to be weaker compared to other countries, e.g. the US.
\end{abstract}

JEL classification: C32, E52, G21

keywords: monetary policy, bank lending channel, interbank market 


\section{Non-technical summary}

A distinctive feature of the German banking system is its sectoral organisation: the vast majority of small banks is affiliated to either the savings banks' or the credit cooperative sector, with large banks serving as head institutions. This organisational structure has consequences for the reaction of banks to monetary policy.

We show that banks react to monetary contractions by redistributing liquidity on the interbank market. The most important movements we identify take place within the savings banks' and the credit cooperative sector, where small and medium-sized banks experience a net inflow of funds from large banks. Large banks, on the other hand, attract liquidity from abroad.

Regarding loans to non-banks, we find that small banks within the two sectors manage to maintain their loan portfolio after a monetary contraction, whereas loans of large banks fall. This suggests that small banks use the redistribution of liquidity in the interbank market to cushion the effects of restrictive monetary policy on their loans to non-banks. This result is compatible with the hypothesis that especially small banks maintain housebank relationships to their customers.

This result has implications for a test on the role of banks in monetary policy transmission. Several recent publications have dealt with this topic for the US economy. The hypothesis that banks reduce their loan supply after a monetary tightening has been tested by looking at the response of loans of different banks. Banks have often been classified in terms of their size, assuming that a small bank will have more difficulties to maintain its lending behaviour than a large bank does. The underlying idea of these tests is that banks have to refinance their loans, and that small banks face a disadvantage with respect to large banks in the markets for these funds.

Given the supportive evidence for the US, this testing strategy has also been applied to Germany and various other countries. This paper argues that such an empirical analysis needs to take into account the characteristics of the national banking structure. The role of size as a determinant of the reaction of a bank's loan supply to monetary policy need not be useful in a case like Germany, since the vast majority of small banks can overcome their disadvantage in accessing funds through their affiliation to a sector with large banks as head institutions. 
Of the various channels transmitting monetary policy, the "credit channel" received major attention in recent research. It is built on the primary insight that financial markets are characterised by an asymmetric distribution of information among the market participants. If in such an environment monetary policy is able to alter the supply of external finance, its effects are unevenly distributed across economic agents: The more severe the informational asymmetry, the more difficult it should be for firms and households to switch between external and internal finance and the more strongly should their spending behaviour be affected.

Within this credit channel theory, the "bank lending channel" concentrates on a specific type of external finance, namely on bank loans. Given that banks are a device to deal with the informational asymmetries between lenders and borrowers, ${ }^{2}$ bank loans are not perfectly substitutable by other forms of external finance, at least for some borrowers. If therefore banks react to restrictive monetary policy impulses by reducing their loan supply, especially those firms and households should be affected that have to rely on bank loans. This is in contrast with the traditional interest rate channel of monetary transmission, which derives effects of monetary policy through interest rate effects on loan demand rather than on loan supply.

Both firm and bank data have frequently been used to test for the existence of a bank lending channel. ${ }^{3}$ To identify loan demand (which should decrease following a monetary tightening according to the interest rate channel) from loan supply (which is the transmitter in the bank lending channel), size was usually the discriminatory device. ${ }^{4}$ It has been argued that asymmetric information problems are more severe for small firms and banks. As a consequence, they should experience higher financ-

\footnotetext{
${ }^{1}$ For an overview of the different transmission channels see e.g. Cecchetti, S. (1995) and Mishkin, F.S. (1996).

${ }^{2}$ For an overview of different theories on financial intermediation see e.g. Bhattacharya and Thakor (1993) or Kashyap et al. (1999).

${ }^{3}$ For studies using firm data see e.g. Christiano et al. (1996), Gertler and Gilchrist (1994) for the US; for the euro area, Mojon (2000) provides an extensive overview of the available evidence; for Germany, see e.g. Ehrmann (2000).

${ }^{4}$ Some papers also concentrated on the degree of liquidity (see e.g. Kashyap and Stein (2000)) and on capitalisation (see e.g. Peek and Rosengren (1995)).
} 
ing costs and/or a stronger decrease in the availability of funds after a monetary tightening. For the case of banks, this means that small banks should show a larger decline in their lending to non-banks. For the US, the evidence is fairly supportive for this transmission channel. ${ }^{5}$ Therefore, this size-related idea to identify loan supply movements has been applied to other countries, too.

For Germany, only very few such studies were conducted with bank data up to now, which is mainly due to the restricted data availability. Based on BankScope, a dataset covering a sample of (among others) German banks, DeBondt (2000) finds evidence for the reaction of bank lending to monetary policy to be dependent on bank size in a panel econometric analysis. On the other hand, Favero et al. (1999) do not find such evidence using the same database in a cross-sectional analysis. Ehrmann et al. (2001) - testing for a differential reaction of bank loans to monetary policy across banks for France, Germany, Italy, Spain and the euro-area as a whole - do not find evidence for a bank lending channel based on bank size as the discriminating variable. They also show that BankScope is not necessarily a useful database for exercises of this kind. Worms (2001) - using the Bundesbank's bank balance sheet statistics covering all German banks - cannot reject the hypothesis that the reaction of a bank's lending to monetary policy depends on its size, although this effect does not seem to be of macroeconomic importance.

In this paper, we will argue that a study of the bank lending channel in Germany has to consider the peculiarities of the German banking system. Several features might be considered in this respect. For example, the Bundesbank deals with a larger share of banks as counterparties than the Federal Reserve. ${ }^{6}$ This indicates that it is much easier for small banks to access central bank money. Furthermore, the cooperative banks' sector - to which the lion's share of small banks belongs - as well as the savings banks' sector operate funds backed up by mutual guarantees, which serve to recapitalise the respective member institutions or to satisfy the creditors in the case of insolvency. Therefore, even if size were a good proxy for informational asymmetries, those informational problems could well be without immediate conse-

\footnotetext{
See, e.g., Kashyap et al. (1993), Kashyap and Stein (2000).

${ }^{6}$ See Borio (1997), p. 49 and 71.
} 
quences for the lending behaviour of banks, rendering size an inadequate variable to identify loan supply and thereby the bank lending channel.

Furthermore, it has often been argued that the German banking system, characterised to a large extent by relationship lending, weakens the case for the bank lending channel. The German system of "Hausbanken"7, along this line of reasoning, tends to shelter borrowers from the short-term effects of a restrictive monetary policy. Although this might be the case, it is unclear how German banks are able to perform this task given that restrictive monetary policy leads to a drain of (or to a rise in the price for) reserves. This is especially relevant in the case of the small, local banks because they usually are assumed to entertain these close "Hausbank" relationships to their customers. Keeping up the lending relationships could prove to be difficult if they are affected disproportionately strongly from the drain of funds following a monetary contraction.

We will argue that the structure of the German banking system offers the potential to counteract the distributional effects of the bank lending channel. The German interbank market is structured in a way that enables most small banks to attract funds through large banks. Using grouped monthly balance sheet data on all German banks, we show that small banks can alleviate the disproportionate drain of funds on the interbank market. This effect can explain why it has been difficult to detect bank lending channel effects in Germany using bank size as the sole device for identification. ${ }^{8}$

In the remainder of the paper, we will first introduce the dataset underlying our analysis and provide a description of the German interbank market, highlighting the characteristics that give rise to our presumption. Section 3 then describes how we organise the data for the empirical analysis. The subsequent section 4 analyses the reaction of bank loans to non-banks to a restrictive monetary policy shock, where we use the traditional bank size criterion as the discriminatory device. In a very simple

\footnotetext{
${ }^{7}$ See, e.g., Elsas and Krahnen (1998).

${ }^{8}$ Pill (1997) argues similarly that in a small open economy size in itself might not be a good proxy for tests of the bank lending channel. He finds that monetary policy tightenings in Spain are tempered by the ability of banks to borrow abroad. Also, Angeloni et al. (1995) show that the institutional features of national banking systems need
} 
setting that does not use bank-size related control variables for loan demand, we find that small banks do not seem to decrease their lending by more than large banks do. Instead, rather the opposite seems to be the case. Therefore, in section 5 we go on to investigate the interbank flows that follow a restrictive monetary policy impulse, testing our presumption that small banks can indirectly access additional interbank funds. We find that the bulk of small banks, namely those that are part of the savings banks' or the credit cooperative sector, is supplied with funds from the head institutions of their respective sector. By removing all banks that are organised in such a sector from our database and subsequently re-running the simple estimations from section 4 , we are able to show in section 6 that for the remaining banks size matters for the reaction of their loans to non-banks to monetary policy shocks, as predicted by the bank lending channel theory. Section 7 concludes.

\section{The database and the structure of the German interbank market}

The data used in this analysis was taken from the balance sheet statistics of the Deutsche Bundesbank. It comprises individual bank balance sheet data of all German banks for the period 1992-1998 on a monthly basis. The period after 1998 was not used in this study because harmonisation procedures in the uprun to EMU led to a break in the data definitions. The data on interbank assets and liabilities is disaggregated into several maturity categories and contains information on the respective counterparties.

Table 1 contains information on the interbank linkages of the various bank groups. The savings banks hold almost three quarters of their interbank assets vis-à-vis their head institutions (in the case of the credit cooperatives this share stands even higher, at $92 \%$ ). It can also be seen that the savings banks and the credit cooperatives hold only a relatively small share of their interbank assets vis-à-vis banks that are not part of their respective sector (foreign banks and "other" domestic banks). Contrary to this, the head institutions of the two sectors hold about 54\% (savings banks' sector)

to be taken into account for studies of the bank lending channel. They show that, in Italy, large banks increase the interest rates on loans by more than small banks do, a feature related to the existence of customer relationships. 
and about $42 \%$ (cooperative sector) vis-à-vis "other" domestic banks. The largest share of interbank assets vis-à-vis foreign banks is held by the "other" domestic banks, highlighting their close relationships with banks abroad.

Table 1: $\quad$ Structure of interbank assets and liabilities by bank category ${ }^{a}$ $\%$ of total interbank assets or liabilities, respectively

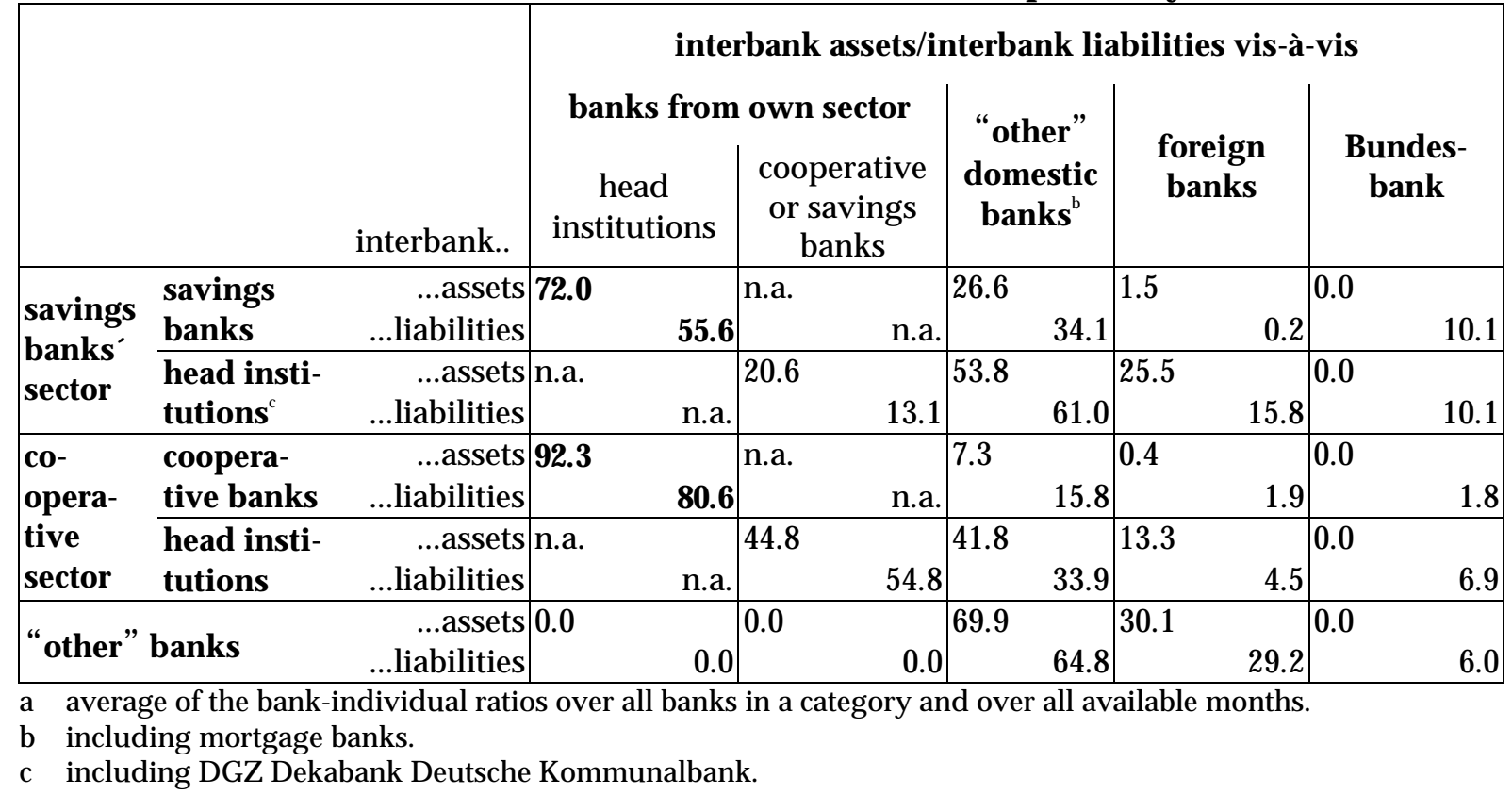

This picture does not change considerably when interbank liabilities are considered. Table 1 therefore leads to the notion, that the "other" domestic banks have close linkages with foreign banks, whereas the head institutions of the two bank sectors have close relationships with the lower level institutions of their respective system and with the "other" domestic banks. While the head institutions of the savings banks' sector do have considerable relationships with foreign banks, the linkages between the cooperative central banks and foreign banks seem to be much weaker. Savings banks and cooperative banks have close relationships almost exclusively with the head institutions of their respective sector.

This leads us to the stylised description of the German interbank market depicted in figure $1:{ }^{9}$ We identify two segments of the German interbank market, the external (see upper part of figure 1) and the internal interbank market (see lower part). The

\footnotetext{
${ }^{9}$ See Upper and Worms (2001) for a more detailed description based on an estimated matrix of bilateral exposures in the German interbank market.
} 
internal interbank market denotes the linkages within the two bank sectors, the cooperative sector and the savings banks' sector. The cooperative banks as well as the savings banks maintain their main lending relationships with their respective head institutions. Almost no lending takes place between the single member banks within the two sectors. It is the head institutions (the Landesbanken for the savings banks and the cooperative central banks for the credit cooperatives) which establish the link to the external domestic interbank market for their whole sector. This external interbank market, in turn, is characterised by multiple lending relationships between all participating banks. It is only the external interbank market that has a non-negligible connection with foreign banks (as will be shown in table 2).

\section{Figure 1: Stylised description of the German interbank market}

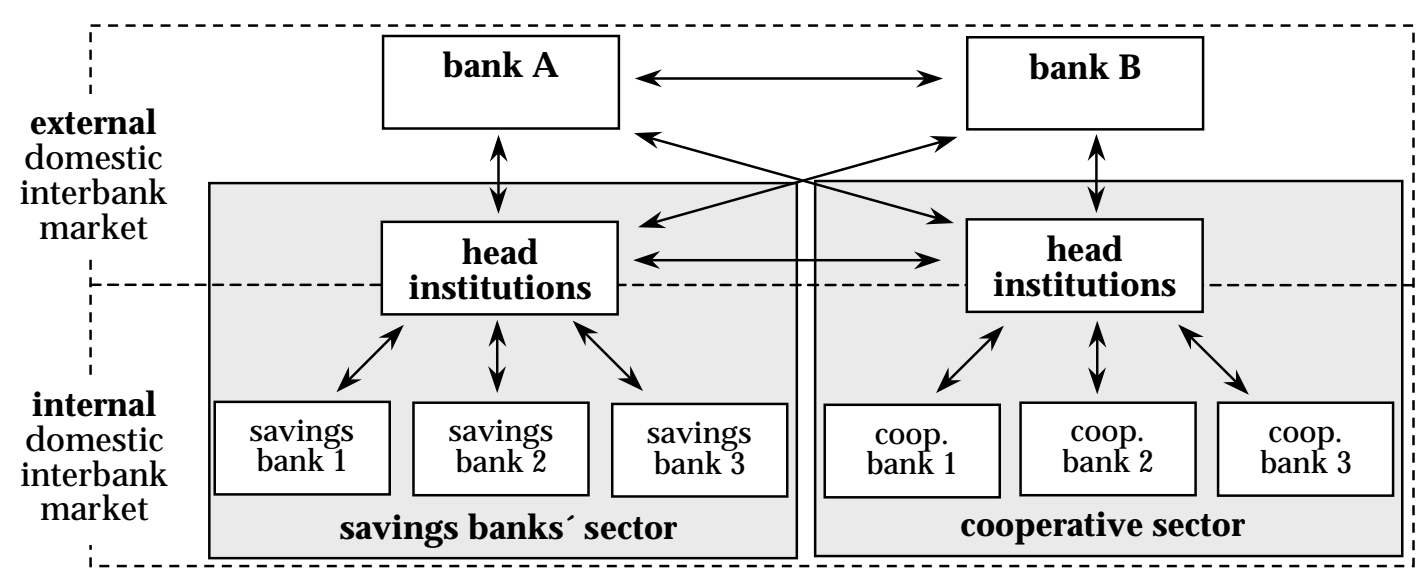

The fact that most small and medium-sized banks are organised within one of the two bank sectors with internal interbank markets (see below) casts doubt on the presumption that large and small banks face a different reaction of their access to funding in case of restrictive monetary policy actions. It can at least not be ruled out a priori that in case of a restrictive monetary policy measure the head institutions of the two bank sectors channel funds to their affiliated small institutions, thus counteracting potential funding problems otherwise faced by these small institutions. In this case, the situation of a small bank following a monetary contraction does not necessarily depend on its size, but rather on its head institutions' availability of funds and on how the funds are allocated within the respective sector. 


\section{Definition of bank size classes and construction of grouped data}

In order to test the hypothesis that the reaction of a bank's interbank borrowing and lending to monetary policy depends on its size, the banks are classified into three size classes. Banks are denoted "small" if at a given point in time their sum of total assets is less than the 75-percentile of the distribution of total assets over all banks. A bank is denoted "large" if its total assets are equal to or larger than the 95percentile. All other banks have "medium size" by definition. Table 2 entails information on the relative importance of these three size groups for June 1995, the middle of our sample period, but the following qualitative remarks on the structure of the German banking system hold for all other periods as well.

\subsection{Descriptive evidence on the size structure of the German banking system}

The group of small banks contains only credit cooperatives (88\%), savings banks and "other" banks. The four cooperative central banks and 13 head institutions of the savings banks' sector all belong to the group of large banks. In this group, only $0.4 \%$ of the cooperative banks could be found. The lion share of all savings banks can be found in the group of medium-sized banks.

Table 2 shows furthermore that there is a glaring heterogeneity with respect to the size of the banks in terms of their share in total assets: While the small banks - by definition $75 \%$ of all banks - hold only about $8 \%$ of total assets, the $5 \%$ largest banks hold almost three quarters of total assets. This heterogeneity - although not that extreme - exists also in terms of the share in total loans to non-banks: 2420 small credit cooperatives hold about $8 \%$ of these loans, whereas 89 large "other" banks hold more than $45 \%$. 
Table 2: $\quad$ Structure of the German banking system (June 1995)

\begin{tabular}{|c|c|c|c|c|c|c|c|}
\hline \multirow[t]{2}{*}{ bank size group } & \multirow{2}{*}{$\begin{array}{c}\text { no of } \\
\text { banks }\end{array}$} & \multirow{2}{*}{$\begin{array}{l}\text { \%-share } \\
\text { in total } \\
\text { assets }\end{array}$} & \multirow{2}{*}{$\begin{array}{c}\text { \%-share } \\
\text { in loans } \\
\text { to } \\
\text { non- } \\
\text { banks }\end{array}$} & \multicolumn{2}{|c|}{$\begin{array}{l}\text { \%-share in gross } \\
\text { domestic interbank }\end{array}$} & \multicolumn{2}{|c|}{$\begin{array}{l}\% \text {-share in gross } \\
\text { foreign interbank }\end{array}$} \\
\hline & & & & assets & $\begin{array}{l}\text { liabili- } \\
\text { ties }\end{array}$ & assets & $\begin{array}{l}\text { liabili- } \\
\text { ties }\end{array}$ \\
\hline small & 2748 & 8.4 & 9.2 & 5.2 & 5.4 & 1.5 & 2.1 \\
\hline $\begin{array}{ll}\text { of which: } & \text { savings banks } \\
& \text { Landesbanken } \\
& \text { credit cooperatives } \\
& \text { coop. central banks } \\
& \text { other banks } \\
\end{array}$ & $\begin{array}{r}139 \\
0 \\
2420 \\
0 \\
189 \\
\end{array}$ & $\begin{array}{l}0.9 \\
0.0 \\
6.8 \\
0.0 \\
0.6\end{array}$ & $\begin{array}{l}1.0 \\
0.0 \\
7.7 \\
0.0 \\
0.5\end{array}$ & $\begin{array}{l}0.3 \\
0.0 \\
4.2 \\
0.0 \\
0.7\end{array}$ & $\begin{array}{l}0.7 \\
0.0 \\
3.9 \\
0.0 \\
0.8\end{array}$ & $\begin{array}{l}0.0 \\
0.0 \\
0.0 \\
0.0 \\
1.5\end{array}$ & $\begin{array}{l}0.0 \\
0.0 \\
0.2 \\
0.0 \\
1.8\end{array}$ \\
\hline medium & 733 & 17.5 & 18.9 & 9.1 & 15.6 & 7.5 & 9.8 \\
\hline $\begin{array}{ll}\text { of which: } & \text { savings banks } \\
& \text { Landesbanken } \\
\text { credit cooperatives } \\
\text { coop. central banks } \\
\text { other banks }\end{array}$ & $\begin{array}{r}420 \\
0 \\
200 \\
0 \\
113 \\
\end{array}$ & $\begin{array}{r}10.8 \\
0.0 \\
3.9 \\
0.0 \\
2.8 \\
\end{array}$ & $\begin{array}{r}12.1 \\
0.0 \\
4.4 \\
0.0 \\
2.4 \\
\end{array}$ & $\begin{array}{l}4.0 \\
0.0 \\
2.6 \\
0.0 \\
2.5\end{array}$ & $\begin{array}{l}9.1 \\
0.0 \\
1.9 \\
0.0 \\
4.6\end{array}$ & $\begin{array}{l}0.1 \\
0.0 \\
0.1 \\
0.0 \\
7.3\end{array}$ & $\begin{array}{l}0.1 \\
0.0 \\
0.2 \\
0.0 \\
9.6\end{array}$ \\
\hline large & 184 & 74.1 & 71.9 & 85.6 & 79.0 & 91.0 & 88.1 \\
\hline $\begin{array}{ll}\text { of which: } & \text { savings banks } \\
& \text { Landesbanken } \\
& \text { credit cooperatives } \\
& \text { coop. central banks } \\
& \text { other banks }\end{array}$ & $\begin{array}{r}68 \\
13 \\
10 \\
4 \\
89 \\
\end{array}$ & $\begin{array}{r}8.4 \\
17.7 \\
1.0 \\
3.1 \\
43.9 \\
\end{array}$ & $\begin{array}{r}9.8 \\
14.1 \\
1.1 \\
1.0 \\
45.9\end{array}$ & $\begin{array}{r}3.4 \\
28.0 \\
1.3 \\
8.3 \\
44.6 \\
\end{array}$ & $\begin{array}{r}6.8 \\
25.2 \\
0.6 \\
10.7 \\
35.7 \\
\end{array}$ & $\begin{array}{r}0.6 \\
24.7 \\
0.3 \\
3.2 \\
62.1 \\
\end{array}$ & $\begin{array}{r}0.2 \\
20.8 \\
0.0 \\
1.8 \\
65.2 \\
\end{array}$ \\
\hline all banks & 3665 & 100.0 & 100.0 & 100.0 & 100.0 & 100.0 & 100.0 \\
\hline $\begin{array}{ll}\text { of which: } & \text { savings banks } \\
& \text { Landesbanken } \\
& \text { credit cooperatives } \\
& \text { coop. central banks } \\
& \text { other banks } \\
\end{array}$ & $\begin{array}{r}627 \\
13 \\
2630 \\
4 \\
391 \\
\end{array}$ & $\begin{array}{r}20.1 \\
17.7 \\
11.7 \\
3.1 \\
47.4 \\
\end{array}$ & $\begin{array}{r}22.9 \\
14.1 \\
13.2 \\
1.1 \\
48.8 \\
\end{array}$ & $\begin{array}{r}7.7 \\
28.0 \\
8.1 \\
8.3 \\
47.8 \\
\end{array}$ & $\begin{array}{r}16.6 \\
25.2 \\
6.4 \\
10.7 \\
41.1 \\
\end{array}$ & $\begin{array}{r}0.7 \\
24.7 \\
0.4 \\
3.2 \\
70.9 \\
\end{array}$ & $\begin{array}{r}0.3 \\
20.8 \\
0.4 \\
1.8 \\
76.6 \\
\end{array}$ \\
\hline
\end{tabular}

The 17 head institutions of the two bank sectors hold about one third of all (gross) domestic interbank assets and liabilities, the "other" banks almost half of the interbank assets and about $40 \%$ of the interbank liabilities. Due to the fact that these banks belong to the group of large banks, this group holds $86 \%$ of all domestic interbank assets and $79 \%$ of all domestic interbank liabilities. This indicates, that the head institutions of the two sectors play an outstanding role in the German interbank market.

Table 2 also shows that about 90\% of (gross) foreign interbank liabilities and assets are held by the group of large banks. The share of foreign interbank assets and liabilities held by savings banks and the cooperative sector as a whole is negligible, so that about $95 \%$ are held solely by the Landesbanken and the group of "other" banks. This confirms the description in the last section: It is mainly the group of large banks (and there almost exclusively the Landesbanken and the "other" banks) that have lending and borrowing relationships to foreign banks. 


\subsection{Construction of grouped time series}

The grouped time series are constructed as follows: In a first step, for every single period $t$, every bank is categorised as being small, medium or large. In a second step, the individual asset and liability positions are added up groupwise for every period (methodology (1)). This allows banks to change the size group from period to period. ${ }^{10}$ Therefore, changes in the aggregated asset and liability positions of the groups can in principle be caused by two factors: Changes in the composition of the groups or changes in the underlying bank individual asset and liability positions. In order to generate series that are not affected by compositional changes, an additional methodology is applied (methodology (2)). For every period $t$, we assign each bank to one of the three size groups, both for the current and the previous period $t-1$ separately. All banks that are not in the same group for both these periods $t$ and $t-1$ are not taken into account (for the calculation referring to period $t$ only). This creates size groups that contain the same banks in $t$ and in $t-1$. Then, the individual asset and liability positions of the remaining banks are added up groupwise, for $t$ and $t-1$. Subsequently, period-to-period growth rates of the respective positions are calculated on the basis of this groupwise aggregated data, leading to a time series of consistent growth rates. In the last step, these growth rates are used to construct a time series of volumes by multiplying the (cumulated) growth rates with the respective starting value in January 1992.

Methodology (2) creates time series of grouped asset and liability volumes that change only due to movements in the underlying individual balance sheet positions. Since both methodologies have their specific drawbacks - (1) is sensitive to compositional changes, (2) does not necessarily contain the "true" value of the balance sheet positions of the group at hand - we perform the econometric analysis for both types of grouped data. Furthermore, the data generated by methodology (1) is used in lev-

\footnotetext{
${ }^{10}$ On average, about 19 banks move from one size group into another group in every month. This is mainly due to changes in the threshold values caused by the reduction in the population and to a small extent by extraordinary increases in the size of single banks caused by mergers. On average, about 12 group switches per month could be explained by these two factors, leaving only about 7 changes that are due to a comparatively strong or weak change in total assets. This corresponds to only $0.2 \%$ of the respective population of banks, which should be negligible. We can therefore rule out the possibility that compositional changes of the groups are endogenous, i.e. caused by monetary policy.
} 
els (measured in 1000 DM) and alternatively in ratios, i.e. as shares of total assets. Here, we take account of the type of position we look at, when determining the denominator: if the numerator is a net position, e.g. interbank assets net of a specific interbank liability position, then the denominator is the comparable net position, e.g. total asset net of this specific interbank liability position.

Figure A1 shows the time series of the net interbank positions calculated with methodology (1). The upper panel represents the overall interbank position of small, medium-sized and large banks. The series in the second panel report the positions of banks on the "external" interbank market, i.e. those positions that are not held within the savings banks and the cooperative sector. Those intra-sectoral balances are shown in the third panel. Finally, the fourth panel contains the positions of German banks abroad. A further disaggregation shows that the trending behaviour of many of those series is mainly caused by long-term positions, whereas most of the variability arises in the short maturities of up to three months.

\section{$4 \quad$ Monetary policy and bank loans to non-banks}

In order to analyse the effects of monetary policy on bank loans and later on the interbank market, we employ Structural Vector Autoregressions (SVAR). In particular, we use the identification scheme proposed by King, Plosser, Stock and Watson (1991), since this strategy allows us to explicitly take potential nonstationarities of our time series into account. A detailed discussion of both SVAR models and the identification procedure followed here is provided in the appendix.

Our initial model consists of a four-variate VAR with $X_{t}=\left[\begin{array}{llll}r_{t} & \pi_{t} & y_{t} & l_{t}\end{array}\right]^{\prime}$, where $r_{t}$ stands for a nominal interest rate, $\pi_{t}$ for inflation, $y_{t}$ for real output and $l_{t}$ for the real volume of bank loans to non-banks. Since the interest rate serves as the indicator for the stance of monetary policy, we use the three months money market rate. Inflation and output are important factors in any central bank's reaction function, so it is crucial to include these variables in our system. For a measure of inflation, we opted for producer price inflation rather than consumer prices, since for the sample period under consideration, consumer prices are very much distorted by indirect tax in- 
creases and one-off effects of German unification. The choice of industrial production as the output variable arises naturally, because we want to keep the monthly frequency of the bank balance sheet database. ${ }^{11}$ VARs consisting of an interest rate, inflation and output became a sort of standard or basic framework for empirical monetary policy analysis within the last years. In order to test our hypothesis, which relates to the bank lending channel, we have to enhance this basic framework with a loan variable. ${ }^{12}$ We furthermore include seasonal dummies and a linear trend (which is restricted to lie in the cointegrating space in order to avoid a quadratic trend in the level of the variables). The lag length of our models is chosen such that autoregressive error terms are avoided, which is accomplished by the inclusion of four lags. All models are estimated as Vector Error Correction Models (VECM) in order to allow for cointegration relations between the variables.

As a matter of fact, the cointegration analysis suggests the existence of three cointegration relations (see table A1 in the appendix). A natural candidate for one of these equilibrium relationships is some kind of central bank reaction function. We expect that the Bundesbank, when setting interest rates, took into account inflation and the output gap. ${ }^{13}$ For the sample period under study, it happens to be that output is not subject to a trend. Therefore, measuring the output gap as the deviation of industrial production from trend coincides with the original output variable. Another equilibrium relationship often found in empirical studies is the stationarity of the real interest rate. For the third cointegrating vector, we will test whether bank loans to non-banks $l_{t}$ are cointegrating with interest rates.

\footnotetext{
${ }^{11}$ In Germany, industrial production approximates GDP fairly well, unlike, e.g., in the US.

${ }^{12}$ The loan aggregate we use here is fairly broad. It includes loans to government and to private non-banks, and covers mortgage loans as well as all other loan types. Repeating the analysis with a more homogeneous loan (but smaller) aggregate, i.e. loans to private firms only, does not produce qualitatively different results. Due to the fact that the broader aggregate is of higher macroeconomic importance, we decided to present the results based on this loan variable.

${ }^{13}$ This is compatible with assuming that the Bundesbank followed an intermediate monetary target when setting interest rates. See e.g. Deutsche Bundesbank (1999), esp. p. 53.
} 
The cointegrating vectors are therefore estimated as

\begin{tabular}{c|ccccc} 
& $r_{t}$ & $\pi_{t}$ & $y_{t}$ & $l_{t}$ & $t$ \\
\hline$\beta_{1}{ }^{\prime}$ & $\mathbf{1}$ & $\mathbf{- 1 . 3 6}$ & $-\mathbf{0 . 8 7}$ & 0 & 0 \\
& $(-)$ & $(0.25)$ & $(0.15)$ & $(-)$ & $(-)$ \\
$\beta_{2}{ }^{\prime}$ & $\mathbf{1}$ & $-\mathbf{1}$ & 0 & 0 & $-\mathbf{0 . 0 6}$ \\
& $(-)$ & $(-)$ & $(-)$ & $(-)$ & $(0.02)$ \\
$\beta_{3}$, & $\mathbf{0 . 0 1}$ & 0 & 0 & $\mathbf{1}$ & $-\mathbf{0 . 0 1}$ \\
& $(0.00)$ & $(-)$ & $(-)$ & $(-)$ & $(0.00)$
\end{tabular}

It can be seen that the coefficient on inflation in the monetary policy reaction function is slightly larger than one, as would be adequate in a Taylor-rule framework. The stationarity of real interest rates can be improved by adding a linear trend for this sample period. Bank loans depend negatively on the level of interest rates, which is compatible with both, the bank lending channel and the interest rate channel. The overidentifying restrictions cannot be rejected by a $\chi^{2}$-test (see table A2 in the appendix).

The sample period under inspection is characterised by a trending behaviour of several variables, related to the uprun to EMU and the consequences of German unification, which is reflected also in the real interest rates. This is due to the fact that we have data available only for a short sample period. ${ }^{14}$ Over a longer sample, real interest rates have been found to be stationary without the inclusion of a trend. ${ }^{15}$ Due to the fact that including a trend into the real interest rate cointegration equation is somewhat unappealing from a theoretical point of view, we carried out a sensitivity analysis (see appendix A4). It shows that the inclusion of the linear trend improves the tests on the overidentifying restrictions substantially, but does not affect the qualitative results of the impulse response analysis.

To proceed with the impulse response analysis, it is necessary to identify the monetary policy shock. The first identification restriction we impose is to assume that the shock is transitory, because after some time all variables should return to

\footnotetext{
${ }^{14}$ The short sample also precludes tests for the stability of the empirical results.

${ }^{15}$ See Ehrmann (2000).
} 
baseline. Additionally, we impose the fairly standard assumption that it affects neither inflation nor output within the same month.

The impulse responses are depicted in the first four graphs of figure A2. All responses are presented with $90 \%$ error bounds. It can be seen that a contractionary monetary policy shock leads to a temporary decrease in inflation and output, and that it decreases bank lending significantly. These results are in line with conventional theory. However, the impulse responses show a brief price puzzle ${ }^{16}$ and a surprising initial response of output. Since both of them disappear in the subsequent estimates, we decided not to elaborate on the model at this stage. Both effects do not affect our qualitative results that are based on extended versions of this baseline model.

To see whether the size of banks affects the response of loans to a restrictive monetary policy shock, we re-estimate this model for the group of small and large banks separately. ${ }^{17}$ The bank lending channel predicts that small banks' loan supply to non-banks should decline by more than that of large banks does. This differential reaction is used as an identification device to separate loan supply from loan demand reactions. Assuming that the loan demand responds in the same way for all banks, regardless of their size, a different reaction in bank lending for banks of different size identifies a reaction of loan supply. However, as can be seen in the last two graphs of figure A2 (see appendix), this cannot be found in our experiment: Most of the overall reduction in bank loans seems to be borne by large banks, with small banks showing no significant response at all. This is compatible with the notion that small banks are to some extent insulating their loan customers from monetary policy induced increases in interest rates, which is in line with the relationship banking assumption often met in the case of Germany. To use the size of banks to identify loan supply from loan demand is therefore not suitable for the German case. This implies that the third cointegrating vector can represent either a supply or a demand reaction.

Notwithstanding this identification issue, it remains to be seen how the small banks manage to insulate their lending from monetary policy impulses, because after

\footnotetext{
${ }^{16}$ This is often found for post-unification Germany. See, e.g., Peersman and Smets (2000).

${ }^{17}$ For the results of the cointegration analysis, see the second and third columns of tables A1 and A2.
} 
a restrictive monetary policy shock they should be in need for additional funds in order to be able to do so. The underlying assumption of bank lending channel theories, namely that small banks find it more difficult than large banks to finance their lending following an interest rate increase, does not seem to hold in the German case. There must be a mechanism at work, which enables small banks to overcome these financing problems often assumed to be relevant for other countries. Our hypothesis is that the German interbank market provides some compensation mechanism: even if small banks might see their deposits shrinking by more than large banks or might find it more difficult to access other sources of finance, they will be able to access additional funds on the interbank market. We will test this hypothesis in the subsequent section.

\section{$5 \quad$ Monetary policy and interbank lending}

\subsection{The empirical models}

In this section, the regression models are a slightly adjusted version of the ones in the preceding section. The main macroeconomic variables - interest rates, inflation and industrial production - are kept, whereas the bank loan variable is substituted for by various interbank lending variables. The way we measure bank lending changes somewhat, however: We are only interested in the net position of a bank on the interbank market, since for our purposes it is not relevant whether a bank adjusts its interbank position by adjusting its liabilities or its assets. Since the net position can be either positive or negative, it is not possible to take logarithms of the data. This is not a serious drawback in our case, as the net position should be fluctuating around a balanced position, i.e. around zero, so it cannot be subject to an exponential path in the long run. ${ }^{18}$ The nominal values can increase over time, however.

The estimations are therefore performed in three ways. Firstly, the series of the asset and liability volumes that were achieved with methodology (1) are used. Alternatively, those volumes are used to construct ratios, i.e., the levels are scaled by total

\footnotetext{
${ }^{18}$ Although it should be fluctuating around zero, the variables can deviate from zero for long periods of time. Therefore, they need not be stationary - and indeed, they turn out to be I(1).
} 
assets of the respective group, the latter corrected for interbank liabilities. In a third variant, the series derived with methodology (2) are used to ensure that the results are not driven by changes in the composition of the size classes. This sensitivity analysis is necessary and useful because in the sample period studied, the German banking industry underwent significant changes due to merger and acquisition activities. ${ }^{19}$ We can, however, safely conclude that all three ways of measuring interbank lending yield qualitatively equivalent results.

In order to enhance comparability across models, the monetary policy shock should be identical in all models. Preliminary estimations showed that this can be achieved by keeping one interbank variable in each of the different variants of the model. This provides an "anchor" that limits the deviations between the models to a minimum and creates basically identical responses of interest rates, inflation and industrial production across all different models. The anchor that performs best in this respect is the net interbank position of the group of largest banks in the internal interbank market. In the following, the VARs hence consist of $X_{t}=\left[\begin{array}{lllll}r_{t} & \pi_{t} & y_{t} & l_{1, t} & l_{2, t}\end{array}\right]$, where $l_{1, t}$ denotes this anchor variable, and $l_{2, t}$ stands for various alternative interbank variables that change from specification to specification and that make it possible to test our hypothesis of a differential behaviour across size groups. $^{20}$

The cointegration analysis proceeds along the same lines as above. For most of the models, a cointegrating rank of four results (see table A3 in the appendix). In order to harmonise the various regressions, this rank is maintained for all of the models. The cointegrating vectors regarding the Bundesbank reaction function and real interest rates are restricted to be numerically identical to the ones estimated in the preceding section in each of the models, again to enhance comparability of the results. The other relations are allowed to vary, but relate the interbank lending to interest rates, allowing for a time trend. The overidentifying restrictions can never be

\footnotetext{
${ }^{19}$ For a description, see e.g. Worms (2001).

${ }^{20}$ The anchor is highly collinear with the internal bank lending variables of the other size classes. Nonetheless, the regressions yield practically identical results when estimating a model with both the anchor and another internal bank lending variable or with one internal variable only.
} 
rejected, as is shown in table A4 (see appendix). The estimated cointegration relations of the interbank variables are provided in table A5 (also in the appendix).

\subsection{Segments of the interbank market}

Figures A3 to A5 in the appendix show the impulse responses for the various interbank lending models. The first row in each case depicts the responses of interest rates, inflation and output to a monetary policy shock. Across all models these responses do not differ considerably. Also, the price puzzle has disappeared from all specifications, and the surprising initial output response remains in only one of them. This indicates that the VARs are generally well specified.

The second row looks at lending of banks in the overall interbank market, separately for all three size classes. Since the variables are defined as net asset positions, i.e. assets minus liabilities, a negative reaction signals an increase in the net borrowing of a specific bank group. The impulse responses show that banks of all size categories increase their net borrowing following a monetary contraction. This might seem puzzling at first sight, since the database comprises the full population of German banks. However, the German interbank market is not a closed system, since banks can (and do, as will be shown below) access also the international interbank market. So it seems as if all bank groups had a chance to cushion the restrictive effect of monetary policy by financing their loans following a monetary policy tightening via the interbank market. In the following, we will therefore look at different segments of interbank lending.

The third row of figures A3 to A5 contains the responses of the lending positions in the external interbank market, i.e. excluding intra-sectoral balances. The responses of banks' positions are quite revealing. Small banks do not increase their borrowing in this market segment, whereas medium-sized and large banks attract additional finance through this channel. These impulse responses are in line with the bank lending channel theory. If this were the only source of interbank credit, small banks would face a deterioration of their financing situation, and as such would be forced to restrict their bank lending by more than large banks. 
The channel that distinguishes the German from the US banking system and that counteracts these distributional effects of monetary policy is analysed in row 4 of figures A3 to A5. Here, we look at positions on the internal interbank market. It turns out that small banks raise additional funds following a monetary tightening in this market segment. Actually, virtually all of their borrowing in the overall interbank market is supplied through the intra-sectoral links, as can be seen by comparing the magnitude of responses in rows 2 and 4. Similarly, medium-sized banks borrow on the intra-sectoral segment, and get the bulk of their financing needs from this source. On the other hand, the group of large banks, which includes all head institutions of both the savings banks' and credit cooperative sectors, turns out to be a net lender after the monetary contraction.

The last market segment that can be distinguished is bank lending from abroad. This aggregate consists of all interbank positions of German banks with banks abroad, including foreign branches of German banks. ${ }^{21}$ Here, again, the responses are in line with the assumptions of bank lending theories - the results are compatible with the notion that small banks suffer from informational disadvantages that prevent them from increasing their exposure to the international interbank market. The most important players in this market are the largest banks, which receive the main parts of their additional borrowing from abroad. The results are therefore consistent with the notion that after a restrictive monetary policy measure the group of large banks borrows funds from abroad that are then channelled to the small and mediumsized banks by the head institutions of the two bank sectors. This inflow of funds can of course take different forms, either an increased borrowing or a withdrawal of deposits, either at foreign banks or at the foreign branches of the German banks.

\footnotetext{
${ }^{21}$ On average over the sample period 1992-1998, around 55\% of these interbank positions were denominated in $\mathrm{DM}$. The remaining positions are converted into DM at the current exchange rate. This leads to some ambiguity in the impulse responses: if an interest rate increase leads to an exchange rate appreciation, then this c.p. lowers the reported DM-value of the interbank positions. In our estimations, we would therefore report a fall in the net position of German banks. However, we consider the size of this bias likely to be smaller than the overall effect we observe. Firstly, because it concerns less than $50 \%$ of the positions, and secondly because the magnitudes of the actual responses would be unreasonably large if they were induced by exchange rate changes only: In figure $\mathrm{A} 3$, e.g., a 5 basis point interest rate increase lowers the net foreign interbank positions by $0.8 \%$. We would expect the exchange rate effect to be much smaller. Under the assumption that small banks do not actively change their positions abroad, a rough guess of this magnitude could be found by the response of this position, which is around $0.004 \%$.
} 
The results from this analysis are surprisingly clear, and furthermore robust to all three ways of defining the interbank lending variables: the German system of intrasectoral linkages across banks tends to alleviate possible disadvantages of small banks on the interbank market. By accessing the external interbank market through their head institutions, which themselves belong to the group of large banks, small banks may overcome size related market frictions. Whether this mechanism enables them to completely overcome possible disadvantages nevertheless remains an open question. But, if this were the case, small banks that are organised within one of the two sectors would not face a disproportionately strong drain of liabilities following a monetary contraction compared to larger banks. But, we can at least say that cooperative banks and savings banks should be more able to shelter their lending to nonbanks from interest rate shocks than are banks of similar size that do not belong to one of the two sectors.

\subsection{The maturity structure in the interbank market}

The data collected by the Deutsche Bundesbank are disaggregated according to the maturity structure of interbank lending. We had imposed the identification assumption that a monetary policy shock constitutes a transitory phenomenon for all included variables, an assumption that would be supported if the interbank lending following such a shock were short term in nature. To test this hypothesis, we decompose the interbank lending into short-term (up to three months) and long-term lending (larger than three months), and repeat the analysis for both maturity categories. Figures A6 and A7 (see appendix) give the according results, confirming our hypothesis: Long-term lending does not seem to play any role in the reaction to a monetary policy shock; virtually all the reaction takes place in the short-term maturities. This is interesting mainly with respect to the intra-sectoral results. It is well known that, on average, the intra-sectoral positions are a device for maturity transformations: "The savings banks and credit cooperatives lend mostly short-term funds to the central institutions whereas the latter, by contrast, return mainly longer-term deposits to the 
primary institutions. ${ }^{\prime 22}$ Although this is certainly true in equilibrium, it is also the case that the central institutions act as a provider of short-term funds in times of monetary contractions (or, as will be shown in the next section, rather as an absorber of shortterm funds in times of monetary easing).

\subsection{The reaction of internal interbank market positions}

As has been seen in section 5.2, it is the internal interbank market that performs a redistributive task following a monetary policy shock. The groups of small and medium-sized banks borrow funds after a tightening, which are supplied by the group of large banks. Since the analysis had only considered net positions so far, we are not able to tell whether the groups of smaller banks withdraw funds they had deposited with their head institutions, or whether they take up new loans. Figure A8 in the appendix provides the impulse response analysis of the gross positions on the internal interbank market. The groups of small and medium-sized banks reduce their asset holdings on the internal interbank market, which is reflected in a reduction of the liabilities on the side of the group of large banks. Medium-sized banks furthermore take up new loans; this reaction is quantitatively much less important than the reduction of assets, and as such not reflected in a significant response of the asset side of the group of large banks.

It can therefore be concluded that the savings banks and credit cooperatives deposit short-term funds with their head institutions, when they have an ample supply of such funds (like for example following a monetary easing) and that in times of shortages, these funds can be withdrawn and flow back to the smaller banks.

Interestingly, the head institutions of the two sectors react to these outflows of funds by adjusting their lending to non-banks accordingly. Following a monetary tightening, they face an outflow of funds to the affiliated institutions, and consequently reduce their loans to non-banks significantly. It turns out that the decrease of bank lending to non-banks for the group of large banks (shown in figure A2) is mostly borne by the head institutions: separating the response of the large banks into

\footnotetext{
${ }^{22}$ Deutsche Bundesbank (2000), p.51.
} 
the head institutions and the other large banks, we find a significant negative response of the head institutions, whereas that of the other large banks is only insignificantly negative.

\section{$6 \quad$ Loans from banks without intra-sectoral links}

The preceding section has shown that the system of bank sectors can in principle serve as a powerful tool for overcoming distributional effects of monetary policy across banks of different size. Logically, the question arises, whether the results obtained for the reaction of loans to non-banks in section 4 will change if only banks without intra-sectoral links are considered. To investigate this, we have removed all banks from our sample that report non-zero intra-sectoral positions. None of the remaining banks can access the internal interbank market of the savings banks or credit cooperative sectors. We are left with only very few banks in the group of small and medium-sized banks (in June 1995 only 91 out of 3665 banks), which are quantitatively negligible (in June 1995 their market share in bank lending amounts to only $0.7 \%$ ). The response of their loans to non-banks to a monetary contraction is shown in figure A9 (see appendix), and compared to the response of loans by the largest banks (again, excluding all banks which are part of a sectoral system). Loans to non-banks from smaller banks show no significant reaction instantaneously, but strongly decrease in the subsequent months. This reaction is much more pronounced than that of the large banks, and additionally takes much longer to return to baseline. ${ }^{23}$ This is the size-related result usually obtained in empirical studies for other countries that have a banking system without some sort of internal interbank market.

Due to the fact that both lending variables were included in the same model, it is possible to apply simple t-tests on which reaction coefficient is stronger. ${ }^{24}$ The following table presents the results:

\footnotetext{
${ }^{23}$ Using the narrow loan aggregate (loans to private firms and to self-employed only), we find a similar decrease in the loans of small and medium-sized banks, and no significant response of the loans of large banks. The t-tests show that the reaction of bank lending is much stronger for the smaller bank groups, also for this loan aggregate.

${ }^{24}$ We are reporting the tests for single time periods rather than the whole impulse responses, since the calculation of the latter necessitates cumbersome calculations of the covariances for all periods and all variables.
} 


\begin{tabular}{l|cccccccccc}
\hline Period & 0 & 1 & 2 & 3 & 4 & 5 & 6 & 7 & 8 & 9 \\
\hline $\mathrm{t}$-stat & -1.34 & 0.71 & $\mathbf{1 . 9 9}^{* *}$ & $\mathbf{1 . 5 4}^{*}$ & $\mathbf{1 . 3 7}^{*}$ & $\mathbf{2 . 0 0}^{* *}$ & $\mathbf{1 . 6 8}^{* *}$ & $\mathbf{1 . 3 2}^{* *}$ & 1.23 & 1.08 \\
\hline
\end{tabular}

We test a one-sided null hypothesis, namely that large banks react at least as strongly with their lending to a monetary policy shock than does the group of small and medium-sized banks $\quad\left(H_{0}: \theta_{\text {large }} \geq \theta_{\text {small }+ \text { medium sized, }}\right.$ or, alternatively $\left.H_{0}: \theta_{\text {large }}-\theta_{\text {small }+ \text { medium sized }} \geq 0\right)$. Therefore, we can reject the null whenever the $\mathrm{t}$ statistic exceeds the critical value of 1.65 (5\% significance level), or 1.28 (10\% significance level). The test results are rather clear: For periods 2 to 7 , we can reject the null. Only for the period in which the monetary policy shock occurs can the opposite hypothesis be rejected. There is a clear support for a stronger reaction of loans from small banks following a monetary policy contraction once all banks that belong to a bank sector are removed from our sample. However, it has to be kept in mind that this is only a very small fraction of all German banks and as such should not be of major concern to policy makers.

\section{Conclusions}

This paper has provided an empirical analysis of how interbank lending reacts to a monetary policy contraction. Using the bank balance sheet database of the Deutsche Bundesbank, which covers all German banks, we have constructed size-sorted time series to test hypotheses related to the bank lending channel theory. Several recent contributions have argued that a meaningful test for the existence of such a bank lending channel can be performed by analysing the reaction of bank loans following a monetary policy shock: the loans of small banks, it is claimed, should fall by more than those of relatively larger banks.

We have argued that, contrary to this reasoning, size in itself might not be a good proxy to test for the bank lending channel in the German case. The majority of small German banks is organised within either the savings banks' sector or the credit cooperative sector. These sectors seem to access the interbank market as a whole, with the large head institutions establishing the link between the external and the intra- 
sectoral interbank market. The reaction of banks that are part of such a sector is therefore not only dependent on the characteristics of the single bank, but also on the position of the sector on the external interbank market.

It has been shown that, following a monetary contraction, funds are channelled from the head institutions of the two sectors to their affiliated small banks. Large banks on average access the international interbank market to dampen the liquidity drain following a monetary contraction, and then funds are redistributed through the internal interbank market of the two sectors to smaller banks via the head institutions.

Small banks do not seem to play a major role on the external interbank market. Their only source of additional funds is the internal interbank market. Neither the domestic external market nor the international interbank market are accessed by the group of small banks.

We have furthermore shown that applying a size measure to test for the existence of a bank lending channel is much more appropriate in the German case once all the banks that are organised in one of the two sectors are removed from the sample. In this case, the size of a bank significantly affects the reaction of its loan volume to monetary policy impulses: loans to non-banks from small banks decrease by more than those from large banks do. However, it has to be noted that only very few small banks are outside the banking sectors and as such subject to these distributional effects of monetary policy. 


\section{Bibliography}

Angeloni, I./Buttiglione, L./Ferri, G./Gaioitti, E. (1995): The Credit Channel of Monetary Policy Across Heterogeneous Banks: The Case of Italy, in: Banca d'Italia Temi di Discussione No. 256.

Bhattacharya, S./Thakor, A.V. (1993): Contemporary Banking Theory; in: Journal of Financial Intermediation 3, pp. 2-50.

Borio, C.E.V. (1997): Monetary Policy Operating Procedures in Industrial Countries, in: BIS Working Paper No. 40.

Cecchetti, S. (1995): Distinguishing Theories of the Monetary Transmission Mechanism, in: Federal Reserve Bank of St. Louis Review 77, pp. 83-97.

Christiano, L./Eichenbaum, M./Evans, C. (1996): The Effects of Monetary Policy Shocks: Evidence from the Flow of Funds, in: Review of Economics and Statistics 78, pp. 16-34.

DeBondt, G.J. (2000): Financial Structure and Monetary Transmission in Europe -A Cross-Country Study. Cheltenham: Edward Elgar.

Deutsche Bundesbank (1999): Taylor interest rate and Monetary Conditions Index; in. Monthly Report, April 1999, pp. 47-63.

Deutsche Bundesbank (2000): Longer-term trend in German credit institutions' interbank operations, in: Monthly Report, January 2000, pp. 49-68.

Ehrmann, M. (2000): Firm Size and Monetary Policy Transmission: Evidence from German Business Survey Data, in: ECB Working Paper No. 21

Ehrmann, M./Gambacorta, L./Martinez-Pages, J./Sevestre, P./Worms, A. (2001): The role of banks in monetary policy transmission in the euro-area, mimeo (ECB, Banca d’Italia, Banco de Espana, Banque de France, Deutsche Bundesbank).

Elsas, R./Krahnen, J.P. (1998): Is relationship-lending special? Evidence form creditfile data in Germany, in: Journal of Banking and Finance 22, pp. 1283-1316.

Favero, C.A. /Giavazzi, F./Flabbi, L. (1999): The Transmission Mechanism of Monetary Policy in Europe: Evidence from Bank's Balance Sheets; in: NBER working paper No. 7231.

Gertler, M./Gilchrist, S. (1994): Monetary Policy, Business Cycles, and the Behavior of Small Manufacturing Firms, in: Quarterly Journal of Economics 109, pp. 309-340. 
Johansen, S. (1995): Likelihood-Based Inference in Cointegrated Vector Autoregressive Models. Oxford: Oxford University Press

Kashyap, A.K./Rajan, R.G./Stein, J.C. (1999): Banks as Liquidity Providers: An Explanation for the Co-Existence of Lending and Deposit-Taking; in: NBER Working Paper No. 6962.

Kashyap, A.K./Stein, J.C. (2000): What Do a Million Observations on Banks Say About the Transmission of Monetary Policy?; in: American Economic Review 90/3 (June 2000), pp. 407-428.

Kashyap, A.K./Stein, J.C./Wilcox, D.W. (1993): Monetary Policy and Credit Conditions: Evidence from the Composition of External Finance; in: American Economic Review 82, pp. 78-98.

King, R.G./Plosser, C.I./Stock, J.H./ Watson, M.W. (1991). Stochastic Trends and Economic Fluctuations, in: American Economic Review 81, pp. 819 -840

Kueppers, M. (2001): Curtailing the Black Box: German banking groups in the transmission of monetary policy, in: European Economic Review, forthcoming

Mishkin, F.S. (1996): The Channels of Monetary Transmission: Lessons for Monetary Policy; in: NBER Working Paper No. 5464.

Mojon, B. (2000): Credit Channel(s) in the euro area: a survey of the distributional effects of monetary policy. Mimeo, ECB

Peek, J./Rosengren, E.S. (1995): Bank Lending and the Transmission of Monetary Policy; in: Peek/Rosengren (eds.): Is Bank Lending Important for the Transmission of Monetary Policy?, in: Federal Reserve Bank of Boston Conference Series No. 39 (June 1995), pp. 47-68.

Peersman, G./Smets, F. (2000). The Monetary Transmission Mechanism in the Euro Area: More Evidence from VAR Analysis. Mimeo, ECB

Pill, H. (1997). Bank Behavior and Monetary Policy in a Small Open Economy. The Case of Spain. Mimeo, Harvard Business School.

Sims, C.A. (1980): Macroeconomics and Reality, in: Econometrica 48, pp. 1-48

Upper, C./Worms, A. (2001): Estimating bilateral exposures in the German interbank market: Is there a danger of contagion?; in: BIS (ed.): Marrying the micro- and macro-prudential dimensions of financial stability; forthcoming.

Warne, A. (1993): A Common Trends Model: Identification, Estimation and Inference, in: University of Stockholm IIES Seminar Paper No. 555

Worms, A. (2001): The reaction of bank lending to monetary policy measures in Germany. Mimeo, Deutsche Bundesbank. 


\section{Appendix}

\section{A1: THE KPSW-APPROACH TO IDENTIFICATION IN STRUCTURAL VECTOR AUTOREGRESSIONS}

Structural Vector Autoregressions (SVARs) go back to the seminal article by Sims (1980). They assume that the economy can be described by a dynamic, stochastic, linear model of the form:

$$
A_{0} X_{t}=A_{1} X_{t-1}+\ldots+A_{k} X_{t-k}+\mu_{t}=A(L) X_{t-1}+\mu_{t} \text {, with } \mu_{t} \sim \text { iid } N\left(0, \Sigma_{\mu}\right)
$$

where $X_{t}$ represents an $n x 1$-vector of endogenous variables, including one or several instrument variables, and $L$ denotes the lag operator. The estimation proceeds with the reduced form

$$
X_{t}=C_{1} X_{t-1}+\ldots+C_{k} X_{t-k}+\varepsilon_{t}=C(L) X_{t-1}+\varepsilon_{t} \text {, with } C_{i}=A_{0}^{-1} A_{i} \text { and } \varepsilon_{t}=A_{0}^{-1} \mu_{t} .
$$

Estimates can be found for the coefficient matrices $C_{i}$ and the variance-covariance matrix of the disturbances $\varepsilon_{t}, \Sigma_{\varepsilon}$. However, of interest are the parameters in the matrices $A_{i}$ and $\Sigma_{\mu}$, which are exactly identified if $n^{2}$ parameters are restricted. A first set of restrictions is found by the assumption of uncorrelated structural errors (i.e. $\Sigma_{\mu}$ diagonal) and by normalising the diagonal elements to unity, yielding $\Sigma_{\mu}=E\left(\mu_{t} \mu_{t}{ }^{\prime}\right)=I_{n}$, which imposes $n(n+1) / 2$ restrictions. Hence, further $n(n-1) / 2$ restrictions are needed. Sims (1980) used a recursive structure to achieve identification, whereas subsequent contributions extended the range of identification schemes by restricting parameters in various matrices of the system. Amongst these are KPSW (1991). They have shown that cointegration properties of the data can be used for identification purposes. A cointegrated VAR model, which is in its Vector Error Correction format (Johansen 1995: 45-49):

$$
\Delta X_{t}=\alpha \beta^{\prime} X_{t-1}+\sum_{i=1}^{k-1} \Gamma_{i} \Delta X_{t-i}+\varepsilon_{t},
$$

has the Granger representation

$$
X_{t}=C \sum_{i=1}^{t} \varepsilon_{i}+C^{*}(L) \varepsilon_{t}+A,
$$

where A depends on initial values, $\beta^{\prime} A=0$, and $C=\beta_{\perp}\left(\alpha_{\perp}{ }^{\prime} \Gamma \beta_{\perp}\right)^{-1} \alpha_{\perp}{ }^{\prime}$ with

$\Gamma=I-\sum_{i=1}^{k-1} \Gamma_{i}$. Equation (A4) shows that the representation in levels is composed of 
two parts, the non-stationary common trends $\alpha_{\perp}{ }^{\prime} \sum_{i=1}^{t} \varepsilon_{i}$ and the stationary part of $C^{*}(L) \varepsilon_{t}$.

The idea behind KPSW is to decompose the shocks $\varepsilon_{t}$ into $r$ shocks that have only transitory effects (on the levels of the variables), and $n-r$ shocks with permanent effects (with $r$ denoting the number of cointegration relations). This is achieved by rotating the system by premultiplying certain matrices. The new set of variables $Y$ is

$$
Y_{t}=\left(\begin{array}{c}
S X_{t} \\
\beta, X_{t}
\end{array}\right)
$$

The matrix $S$ has to satisfy $S C \neq 0$. It follows that the new set of variables consists of $n-r$ non-stationary and $r$ stationary variables. The stationary variables are identical to the cointegrating vectors; their stationarity follows because $\beta^{\prime} C=0$ and $\beta^{\prime} A=0$ :

$$
\beta^{\prime} X_{t}=\beta^{\prime} \beta_{\perp}\left(\alpha_{\perp}^{\prime} \Gamma(1) \beta_{\perp}\right)^{-1} \alpha_{\perp}^{\prime} \sum_{i=1}^{t} \varepsilon_{i}+\beta^{\prime} C^{*}(L) \varepsilon_{t}+\beta^{\prime} A=\beta^{\prime} C^{*}(L) \varepsilon_{t}
$$

This system need not be identified fully; partial identification of either the transitory or the persistent shocks is also possible. This amounts to the imposition of $r(n-r)$ identification restrictions by setting the according covariances of the shocks to zero. These restrictions have been tested for by the test for the cointegrating rank. Instead, however, a different kind of identification restriction is needed, namely a decision in which part of the system the supposed shock is to be found (like in the context of the present paper, where the monetary policy shock is identified in the transitory subsystem). This restriction cannot be tested and has to be justified by economic theory.

To identify the subsystems, additional untested identification restrictions are necessary. If only the shocks with permanent effects are of interest, then $(n-r)(n-r-1) / 2$ additional identification restrictions are needed. In particular, where there are $r=n-1$ cointegration relations, no additional identification restrictions have to be imposed. Should the shocks of interest be the transitory ones, then $r(r-1) / 2$ additional restrictions are sufficient. 


\section{A2: TEST STATISTICS}

Table A1: L-max statistics for the test of cointegration rank

\begin{tabular}{|c|c|c|c|}
\hline & Total bank loans & Bank loans small banks & Bank loans large banks \\
\hline$r=0^{a}$ & 36.24 & 35.93 & 31.36 \\
$r=1^{b}$ & 17.90 & 29.60 & 18.33 \\
$r=2^{c}$ & 12.53 & 17.99 & 13.72 \\
$r=3^{d}$ & $\mathbf{5 . 4 9}$ & 10.77 & $\mathbf{6 . 6 5}$ \\
\hline
\end{tabular}

$90 \%$ critical values: ${ }^{\mathrm{a}} 19.88^{\mathrm{b}} 16.13^{\mathrm{c}} 12.39^{\mathrm{d}} 10.56$

Table A2: Test for 3 cointegrating vectors: Bundesbank reaction function, trendstationary real interest rates, bank lending cointegrates with interest rates and trend

\begin{tabular}{|c|c|c|c|}
\hline & Total bank loans & Bank loans small banks & Bank loans large banks \\
\hline$\chi^{2}(3)$ & 7.66 & 5.95 & 2.91 \\
p-val. & 0.11 & 0.20 & 0.57 \\
\hline
\end{tabular}

Table A3: L-max statistics for the test of cointegration rank,

(a) interbank variables calculated with methodology (1)

\begin{tabular}{|l|ccc|ccc|ccc|ccc|}
\hline & \multicolumn{3}{|c|}{ Interbank market } & \multicolumn{3}{c|}{ External } & \multicolumn{3}{c|}{ Internal } & \multicolumn{3}{c|}{ Abroad } \\
& small & med. & large & small & med. & large & small & med. & large & small & med. & large \\
\hline$r=0^{a}$ & 38.74 & 43.01 & 39.28 & 39.45 & 39.02 & 39.28 & 37.97 & 42.09 & 42.09 & 35.50 & 34.08 & 37.52 \\
$r=1^{b}$ & 27.33 & 30.28 & 24.97 & 22.61 & 27.92 & 24.97 & 31.32 & 31.03 & 31.03 & 26.55 & 27.41 & 25.82 \\
$r=2^{c}$ & 23.84 & 20.86 & 20.46 & 17.44 & 20.6 & 20.46 & 25.18 & 20.16 & 20.16 & 16.61 & 19.76 & 18.78 \\
$r=3^{d}$ & $\mathbf{1 0 . 5 0}$ & 12.84 & 15.15 & 12.44 & 18.55 & 15.15 & $\mathbf{1 1 . 3 1}$ & $\mathbf{1 1 . 5 3}$ & $\mathbf{1 1 . 5 3}$ & 13.42 & 17.07 & 14.60 \\
$r=4^{e}$ & $\mathbf{8 . 0 3}$ & $\mathbf{6 . 1 3}$ & $\mathbf{7 . 6 8}$ & $\mathbf{7 . 0 5}$ & $\mathbf{8 . 7 0}$ & $\mathbf{7 . 6 8}$ & $\mathbf{8 . 1 8}$ & $\mathbf{7 . 8 6}$ & $\mathbf{7 . 8 6}$ & $\mathbf{6 . 4 6}$ & $\mathbf{5 . 1 3}$ & $\mathbf{6 . 7 4}$ \\
\hline
\end{tabular}

$90 \%$ critical values: ${ }^{\mathrm{a}} 23.72^{\mathrm{b}} 19.88^{\mathrm{c}} 16.13^{\mathrm{d}} 12.39^{\mathrm{e}} 10.56$

(b) interbank variables calculated with methodology (1), defined as ratios

\begin{tabular}{|l|ccc|ccc|ccc|ccc|}
\hline & \multicolumn{3}{|c|}{ Interbank market } & \multicolumn{3}{c|}{ External } & \multicolumn{3}{c|}{ Internal } & \multicolumn{3}{c|}{ Abroad } \\
& small & med. & large & small & med. & large & small & med. & large & small & med. & large \\
\hline$r=0^{a}$ & 42.11 & 44.48 & 41.64 & 43.31 & 43.49 & 42.07 & 39.87 & 49.93 & 49.93 & 39.72 & 39.07 & 40.15 \\
$r=1^{b}$ & 29.38 & 26.93 & 32.11 & 22.10 & 25.39 & 31.25 & 33.96 & 29.50 & 29.50 & 26.27 & 29.67 & 33.54 \\
$r=2^{c}$ & 24.74 & 22.45 & 22.84 & 17.74 & 20.34 & 22.47 & 25.34 & 21.11 & 21.11 & 18.48 & 17.70 & 19.87 \\
$r=3^{d}$ & $\mathbf{1 0 . 6 5}$ & $\mathbf{1 1 . 9 5}$ & 15.75 & 12.62 & 14.38 & 15.74 & $\mathbf{1 0 . 3 2}$ & $\mathbf{1 0 . 3 5}$ & $\mathbf{1 0 . 3 5}$ & 12.47 & 17.26 & 15.75 \\
$r=4^{e}$ & $\mathbf{7 . 2 0}$ & $\mathbf{6 . 7 7}$ & $\mathbf{9 . 9 2}$ & $\mathbf{8 . 5 1}$ & $\mathbf{8 . 7 2}$ & $\mathbf{9 . 8 0}$ & $\mathbf{6 . 8 8}$ & $\mathbf{9 . 3 8}$ & $\mathbf{9 . 3 8}$ & $\mathbf{8 . 1 0}$ & $\mathbf{6 . 1 7}$ & $\mathbf{9 . 6 4}$ \\
\hline
\end{tabular}

$90 \%$ critical values: ${ }^{\mathrm{a}} 23.72^{\mathrm{b}} 19.88^{\mathrm{c}} 16.13^{\mathrm{d}} 12.39^{\mathrm{e}} 10.56$

(c) interbank variables calculated with methodology (2)

\begin{tabular}{|l|ccc|ccc|ccc|ccc|}
\hline & \multicolumn{3}{|c|}{ Interbank market } & \multicolumn{3}{|c|}{ External } & \multicolumn{3}{c|}{ Internal } & \multicolumn{3}{c|}{ Abroad } \\
& small & med. & large & small & med. & large & small & med. & large & small & med. & large \\
\hline$r=0^{a}$ & 42.11 & 44.48 & 41.64 & 43.31 & 43.49 & 42.07 & 39.78 & 49.93 & 49.93 & 39.72 & 39.07 & 40.15 \\
$r=1^{b}$ & 29.38 & 26.93 & 32.11 & 22.10 & 25.39 & 31.25 & 33.96 & 29.50 & 29.50 & 26.27 & 29.67 & 33.54 \\
$r=2^{c}$ & 24.74 & 22.45 & 22.84 & 17.74 & 20.34 & 22.47 & 25.34 & 21.11 & 21.11 & 18.48 & 17.70 & 19.87 \\
$r=3^{d}$ & $\mathbf{1 0 . 6 5}$ & $\mathbf{1 1 . 9 5}$ & 15.75 & 12.62 & 14.38 & 15.74 & $\mathbf{1 0 . 3 2}$ & $\mathbf{1 0 . 3 5}$ & $\mathbf{1 0 . 3 5}$ & 12.47 & 17.26 & 15.75 \\
$r=4^{e}$ & $\mathbf{7 . 2 0}$ & $\mathbf{6 . 7 7}$ & $\mathbf{9 . 9 2}$ & $\mathbf{8 . 5 1}$ & $\mathbf{8 . 7 2}$ & $\mathbf{9 . 8 0}$ & $\mathbf{6 . 8 8}$ & $\mathbf{9 . 3 8}$ & $\mathbf{9 . 3 8}$ & $\mathbf{8 . 1 0}$ & $\mathbf{6 . 1 7}$ & $\mathbf{9 . 6 4}$ \\
\hline
\end{tabular}

$90 \%$ critical values: ${ }^{\mathrm{a}} 23.72^{\mathrm{b}} 19.88^{\mathrm{c}} 16.13^{\mathrm{d}} 12.39^{\mathrm{e}} 10.56$ 
Table A4: Test for four cointegrating vectors: Bundesbank reaction function, trend-stationary real interest rates, interbank lending variables cointegrate with interest rates and trend

(a) interbank variables calculated with methodology (1)

\begin{tabular}{|c|ccc|ccc|ccc|cc|c|}
\hline & \multicolumn{3}{|c|}{ Interbank market } & \multicolumn{3}{|c|}{ External } & \multicolumn{3}{c|}{ Internal } & \multicolumn{3}{c|}{ Abroad } \\
& small & med. & large & small & med. & large & small & med. & large & small & med. & large \\
\hline$\chi^{2}(4)$ & 3.67 & 3.10 & 2.21 & 4.27 & 2.40 & 2.21 & 4.34 & 1.51 & 1.51 & 2.09 & 1.43 & 3.03 \\
p-val. & 0.45 & 0.54 & 0.70 & 0.37 & 0.66 & 0.70 & 0.36 & 0.82 & 0.82 & 0.72 & 0.84 & 0.55 \\
\hline
\end{tabular}

(b) interbank variables calculated with methodology (1), defined as ratios

\begin{tabular}{|c|ccc|ccc|ccc|cc|c|}
\hline & \multicolumn{3}{|c|}{ Interbank market } & \multicolumn{3}{c|}{ External } & \multicolumn{3}{c|}{ Internal } & \multicolumn{3}{c|}{ Abroad } \\
& small & med. & large & small & med. & large & small & med. & large & small & med. & large \\
\hline$\chi^{2}(4)$ & 4.92 & 4.60 & 1.79 & 4.09 & 3.43 & 1.69 & 5.08 & 2.02 & 2.02 & 2.25 & 1.89 & 2.31 \\
p-val. & 0.30 & 0.33 & 0.77 & 0.39 & 0.49 & 0.79 & 0.28 & 0.73 & 0.73 & 0.69 & 0.76 & 0.68 \\
\hline
\end{tabular}

(c) interbank variables calculated with methodology (2)

\begin{tabular}{|c|ccc|ccc|ccc|ccc|}
\hline & \multicolumn{2}{|c|}{ Interbank market } & \multicolumn{3}{c|}{ External } & \multicolumn{3}{c|}{ Internal } & \multicolumn{3}{c|}{ Abroad } \\
& small & med. & large & small & med. & large & small & med. & large & small & med. & large \\
\hline$\chi^{2}(4)$ & 5.81 & 1.91 & 2.99 & 1.74 & 1.11 & 3.00 & 3.84 & 1.67 & 1.67 & 1.27 & 2.17 & 1.98 \\
p-val. & 0.21 & 0.75 & 0.56 & 0.78 & 0.89 & 0.56 & 0.43 & 0.80 & 0.80 & 0.87 & 0.70 & 0.74 \\
\hline
\end{tabular}

Table A5: The maintained cointegrating vector concerning the interbank lending variable

(a) interbank variables calculated with methodology (1)

\begin{tabular}{|c|ccc|ccc|ccc|ccc|}
\hline & \multicolumn{3}{|c|}{ Interbank market } & \multicolumn{3}{c|}{ External } & \multicolumn{3}{c|}{ Internal } & \multicolumn{3}{c|}{ Abroad } \\
& small & med. & large & small & med. & large & small & med. & large & small & med. & large \\
\hline \multirow{3}{*}{$r_{t}$} & 0.84 & 2.46 & -0.60 & 0.21 & 1.12 & 0.82 & 0.71 & 1.12 & -1.48 & 0.04 & 0.66 & 1.64 \\
& $(0.06)$ & $(0.15)$ & $(0.35)$ & $(0.04)$ & $(0.05)$ & $(0.42)$ & $(0.05)$ & $(0.13)$ & $(0.14)$ & $(0.02)$ & $(0.05)$ & $(0.43)$ \\
$t$ & -0.02 & -0.02 & -0.22 & -0.01 & 0.01 & -0.28 & -0.01 & -0.04 & 0.06 & -0.01 & 0.01 & -0.30 \\
& $(0.00)$ & $(0.01)$ & $(0.03)$ & $(0.00)$ & $(0.00)$ & $(0.04)$ & $(0.01)$ & $(0.01)$ & $(0.01)$ & $(0.00)$ & $(0.01)$ & $(0.04)$ \\
\hline
\end{tabular}

(b) interbank variables calculated with methodology (1), defined as ratios

\begin{tabular}{|c|c|c|c|c|c|c|c|c|c|c|c|c|}
\hline & \multicolumn{3}{|c|}{ Interbank market } & \multicolumn{3}{|c|}{ External } & \multicolumn{3}{|c|}{ Internal } & \multicolumn{3}{|c|}{ Abroad } \\
\hline & small & med. & large & small & med. & large & small & med. & large & small & med. & large \\
\hline$r_{t}$ & $\begin{array}{c}2.07 \\
(0.15)\end{array}$ & $\begin{array}{c}3.60 \\
(0.25)\end{array}$ & $\begin{array}{l}-0.29 \\
(0.06)\end{array}$ & $\begin{array}{c}0.31 \\
(0.05)\end{array}$ & $\begin{array}{c}1.20 \\
(0.05)\end{array}$ & $\begin{array}{c}0.26 \\
(0.08)\end{array}$ & $\begin{array}{c}1.76 \\
(0.13)\end{array}$ & $\begin{array}{c}1.26 \\
(0.12)\end{array}$ & $\begin{array}{l}-0.46 \\
(0.03)\end{array}$ & $\begin{array}{c}0.07 \\
(0.02)\end{array}$ & $\begin{array}{c}0.64 \\
(0.05)\end{array}$ & $\begin{array}{c}0.45 \\
(0.08)\end{array}$ \\
\hline$t$ & $\begin{array}{c}0.01 \\
(0.01) \\
\end{array}$ & $\begin{array}{r}-0.08 \\
(0.02) \\
\end{array}$ & $\begin{array}{r}-0.07 \\
(0.01) \\
\end{array}$ & $\begin{array}{l}-0.01 \\
(0.00) \\
\end{array}$ & $\begin{array}{c}0.05 \\
(0.01) \\
\end{array}$ & $\begin{array}{r}-0.06 \\
(0.01) \\
\end{array}$ & $\begin{array}{c}0.02 \\
(0.01) \\
\end{array}$ & $\begin{array}{c}0.00 \\
(0.01) \\
\end{array}$ & $\begin{array}{c}-0.01 \\
(0.00) \\
\end{array}$ & $\begin{array}{l}-0.02 \\
(0.00) \\
\end{array}$ & $\begin{array}{c}0.02 \\
(0.01) \\
\end{array}$ & $\begin{array}{r}-0.04 \\
(0.01) \\
\end{array}$ \\
\hline
\end{tabular}

(c) interbank variables calculated with methodology (2)

\begin{tabular}{|c|ccc|ccc|ccc|ccc|}
\hline & \multicolumn{3}{|c|}{ Interbank market } & \multicolumn{3}{c|}{ External } & \multicolumn{3}{c|}{ Internal } & \multicolumn{3}{c|}{ Abroad } \\
& small & med. & large & small & med. & large & small & med. & large & small & med. & large \\
\hline \multirow{3}{*}{$r_{t}$} & 1.13 & 2.02 & -5.68 & 0.32 & 0.67 & -4.05 & 0.65 & 1.28 & -1.58 & -0.02 & -21.2 & 0.50 \\
& $(0.08)$ & $(0.14)$ & $(0.43)$ & $(0.03)$ & $(0.04)$ & $(0.43)$ & $(0.05)$ & $(0.13)$ & $(0.14)$ & $(0.02)$ & $(3.78)$ & $(0.41)$ \\
$t$ & 0.01 & -0.02 & -0.38 & 0.00 & -0.02 & -0.43 & 0.00 & -0.02 & 0.05 & -0.01 & -0.68 & -0.33 \\
& $(0.01)$ & $(0.01)$ & $(0.04)$ & $(0.00)$ & $(0.00)$ & $(0.04)$ & $(0.00)$ & $(0.01)$ & $(0.01)$ & $(0.01)$ & $(0.35)$ & $(0.04)$ \\
\hline
\end{tabular}




\section{A3: FIGURES}

Figure A1: The net interbank positions of the various size groups calculated with methodology (1)

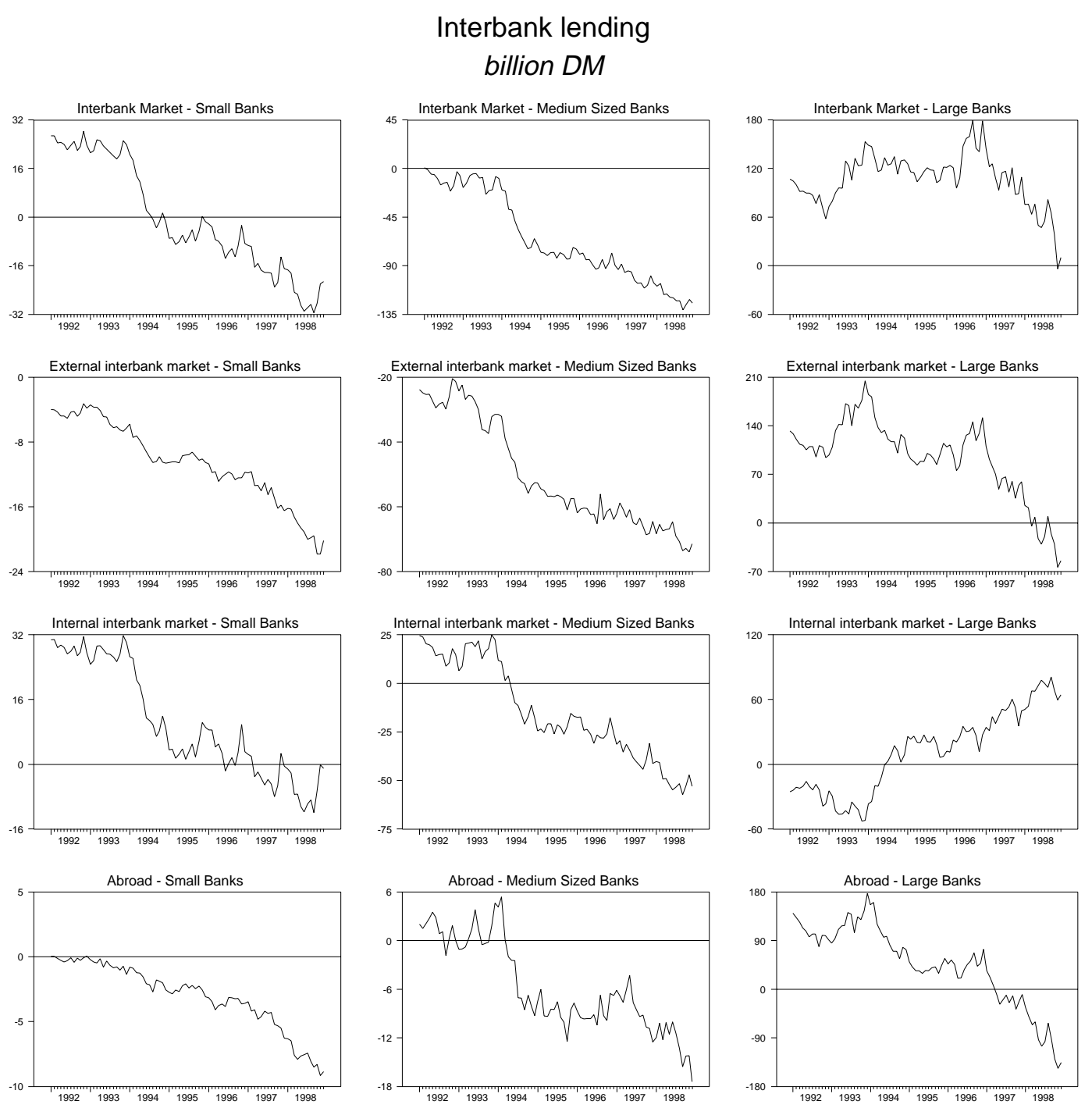


Figure A2: The effects of a monetary policy shock on bank loans to the nonfinancial sector lending; bank variables calculated with methodology (1)

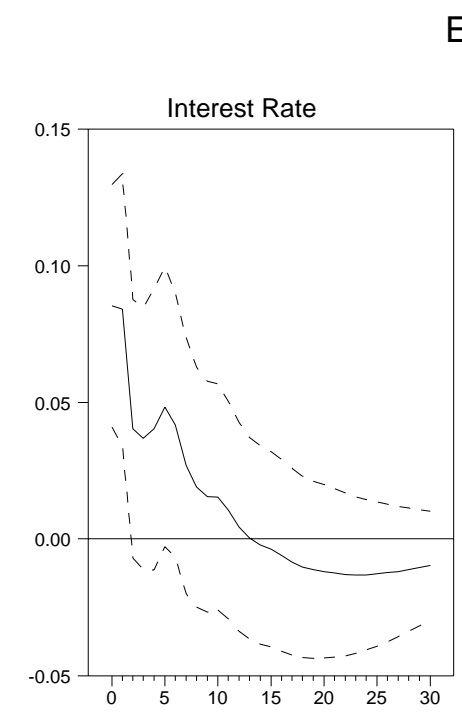

Effect of a Monetary Policy Shock
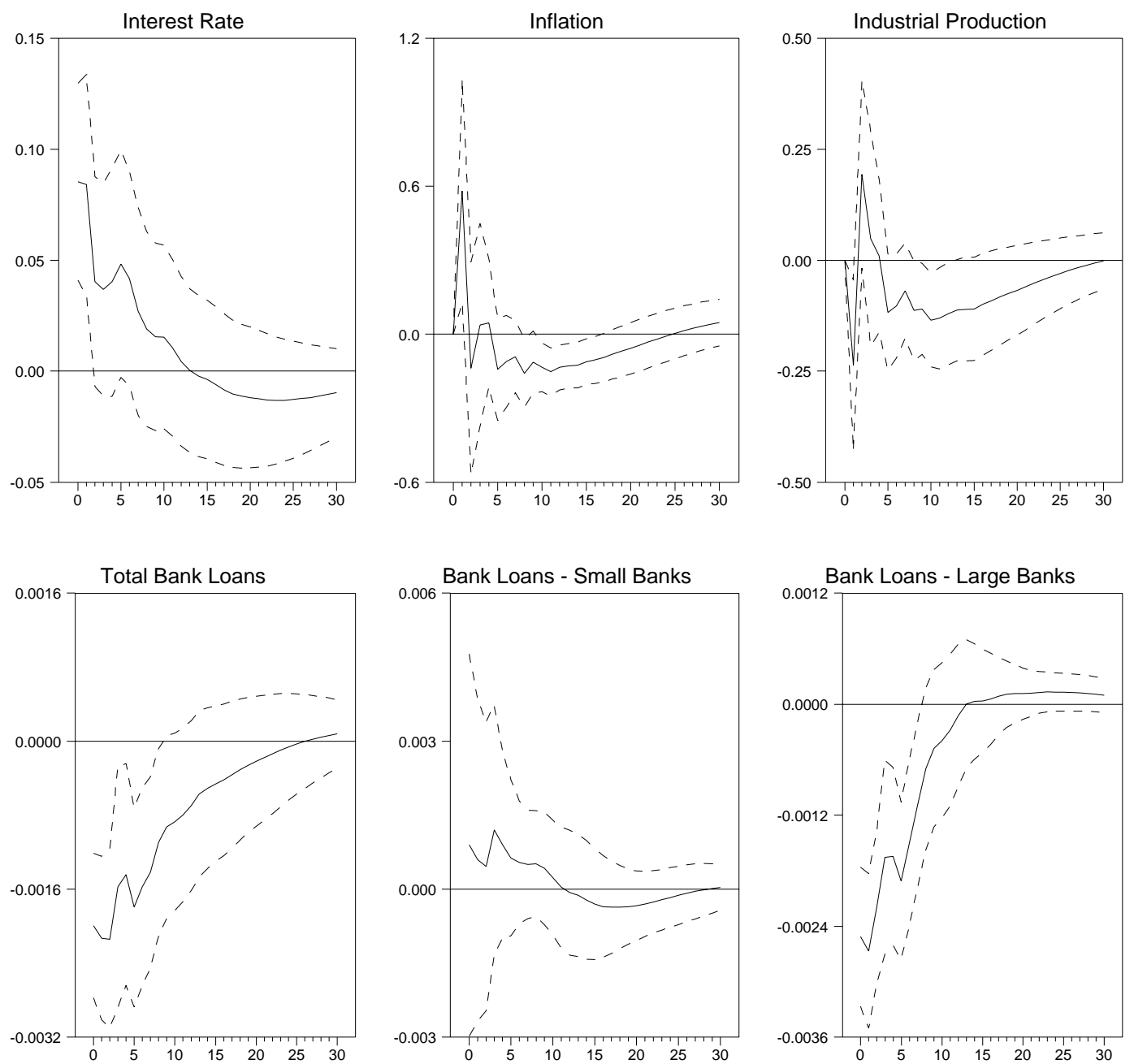
Figure A3: The effects of a monetary policy shock on interbank lending (by the various bank size groups, from different segments of the interbank market); interbank variables calculated with methodology (1)

Effect of a Monetary Policy Shock Interbank variables calculated with methodology (1)
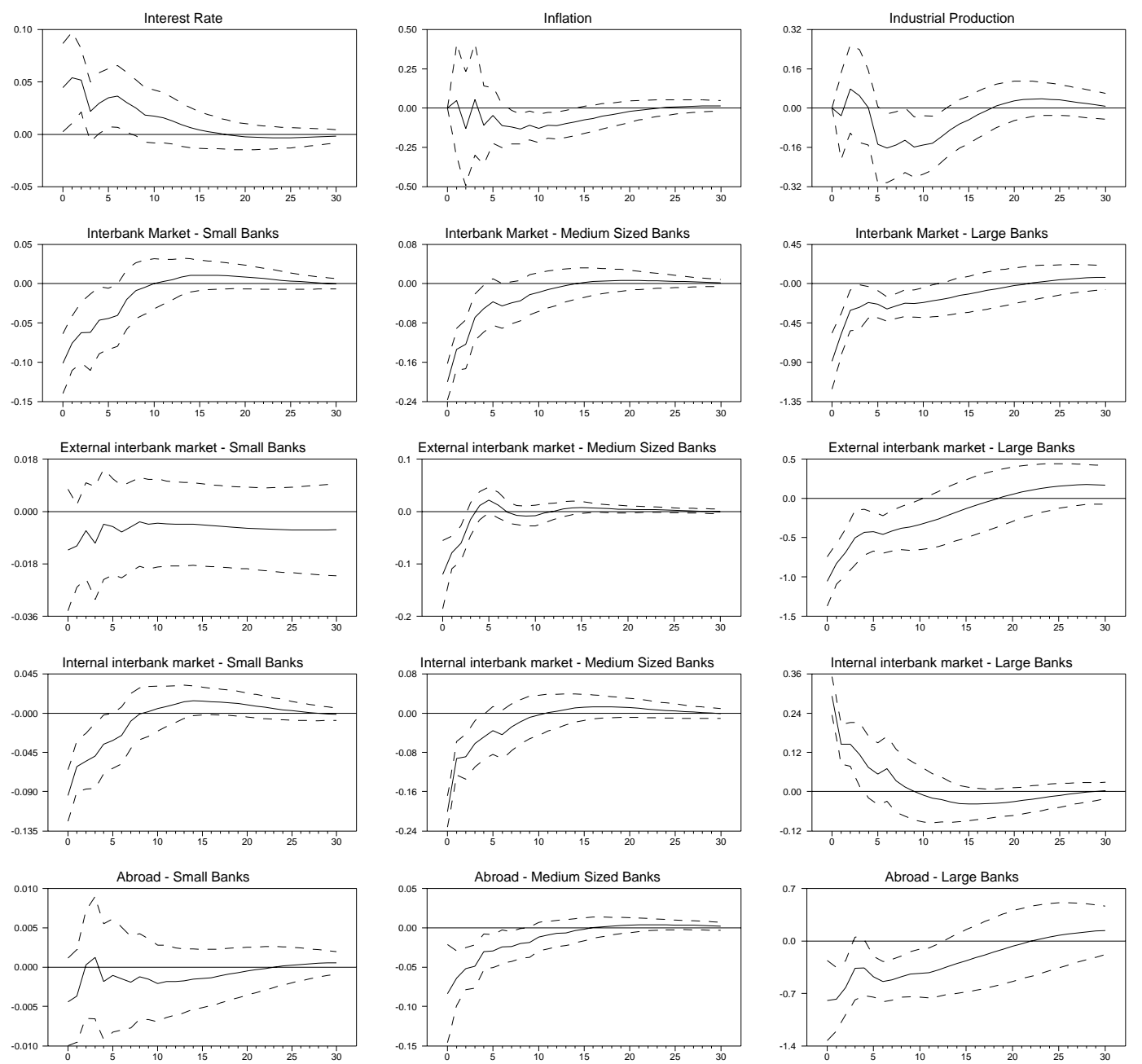
Figure A4: The effects of a monetary policy shock on interbank lending (by the various bank size groups, from different segments of the interbank market); interbank variables calculated with methodology (1), defined in ratios

Effect of a Monetary Policy Shock

Interbank variables calculated with methodology (1), defined in ratios
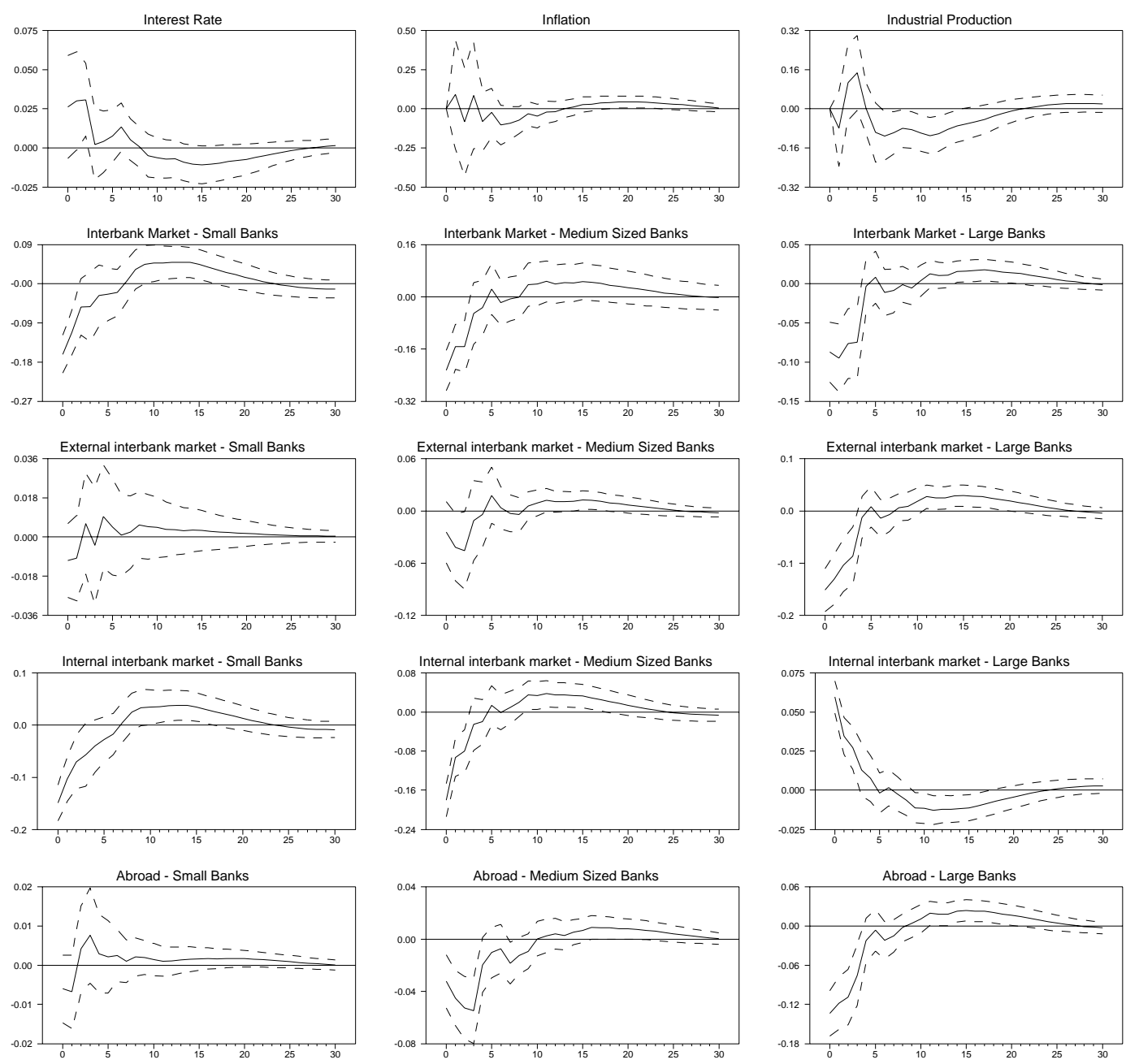
Figure A5: The effects of a monetary policy shock on interbank lending (by the various bank size groups, from different segments of the interbank market); interbank variables calculated with methodology (2)

Effect of a Monetary Policy Shock

Interbank variables calculated with methodology (2)
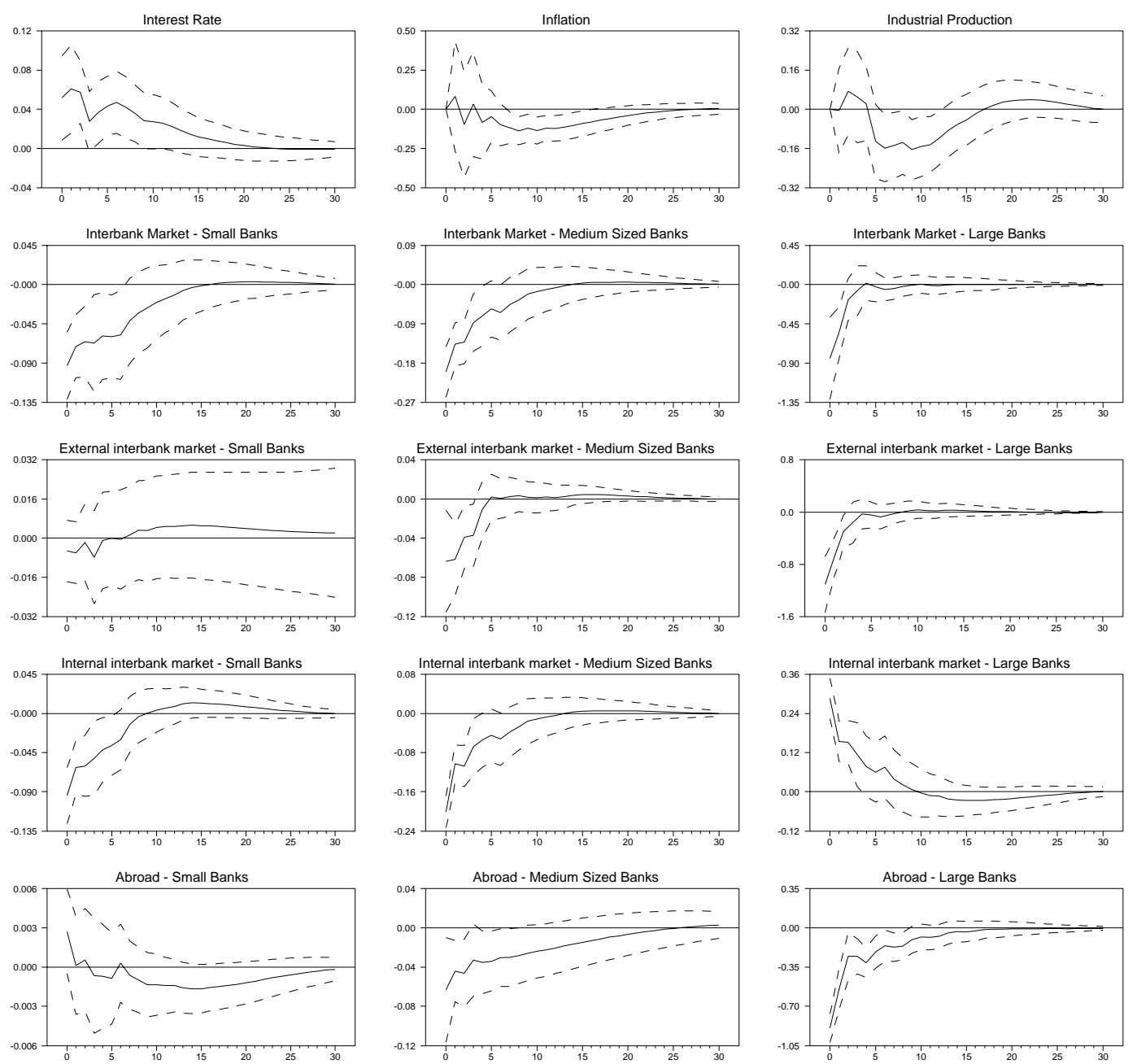
Figure A6: The effects of a monetary policy shock on long-term interbank lending (by the various bank size groups, from different segments of the interbank market); interbank variables calculated with methodology (1), defined in ratios

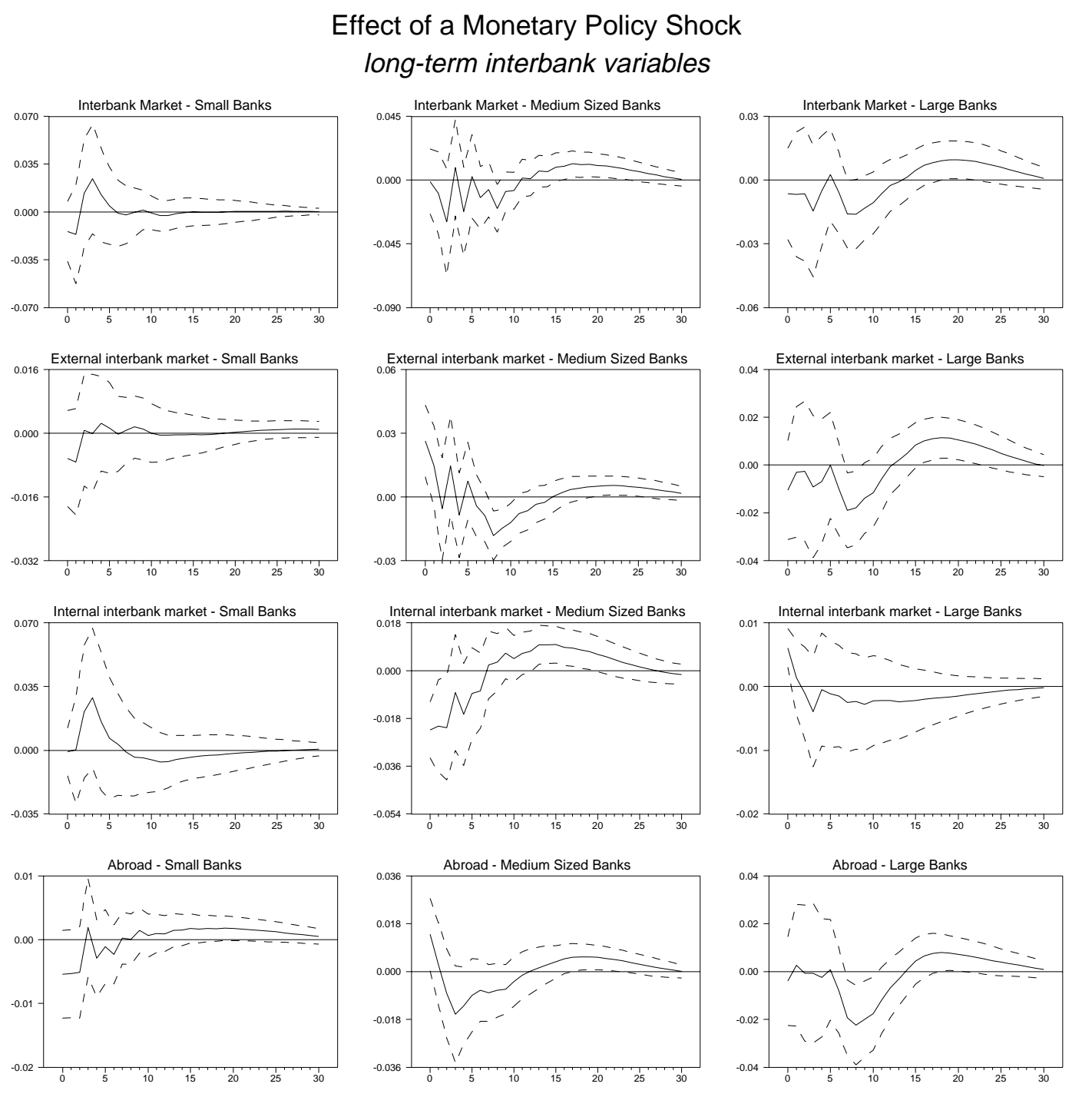


Figure A7: The effects of a monetary policy shock on short-term interbank lending (by the various bank size groups, from different segments of the interbank market); interbank variables calculated with methodology (1), defined in ratios

Effect of a Monetary Policy Shock short-term interbank variables
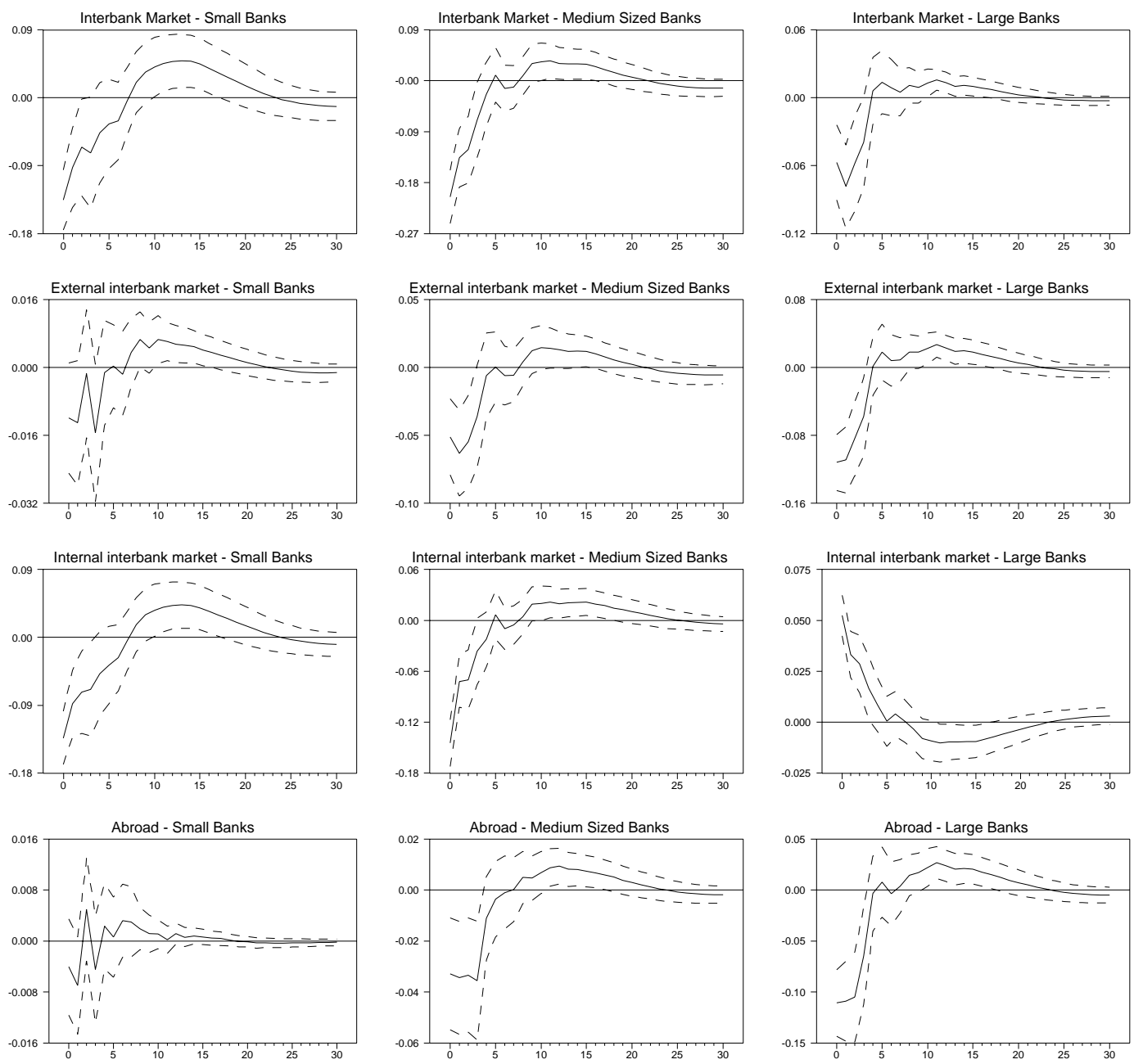
Figure A8: The effects of a monetary policy shock on the internal interbank market; bank variables calculated with methodology (1)

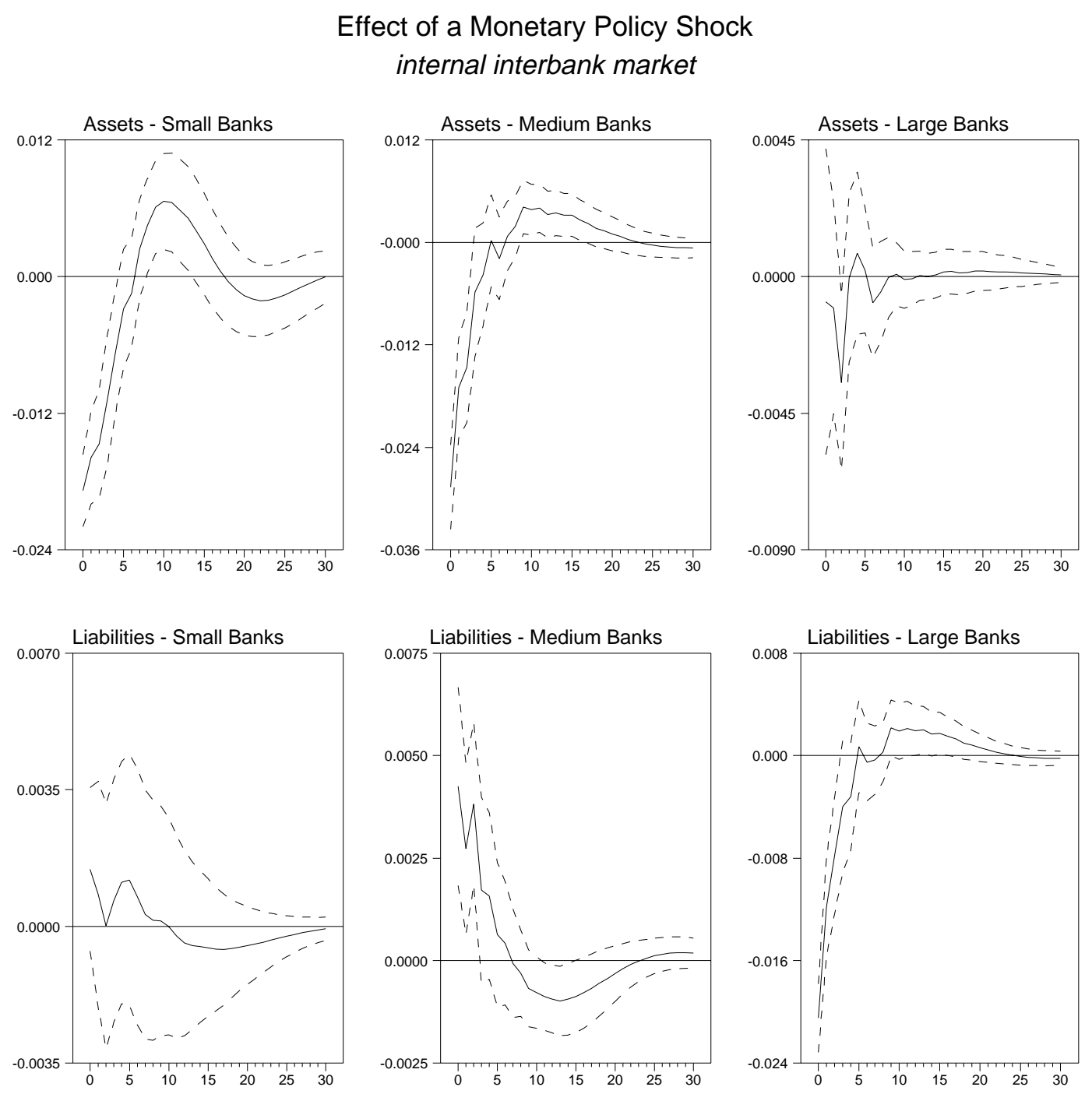


Figure A9: The effects of a monetary policy shock on bank loans to the nonfinancial sector by banks that are neither part of the savings bank sector nor of the cooperative bank sector; bank variables calculated with methodology (1)

Effect of a Monetary Policy Shock
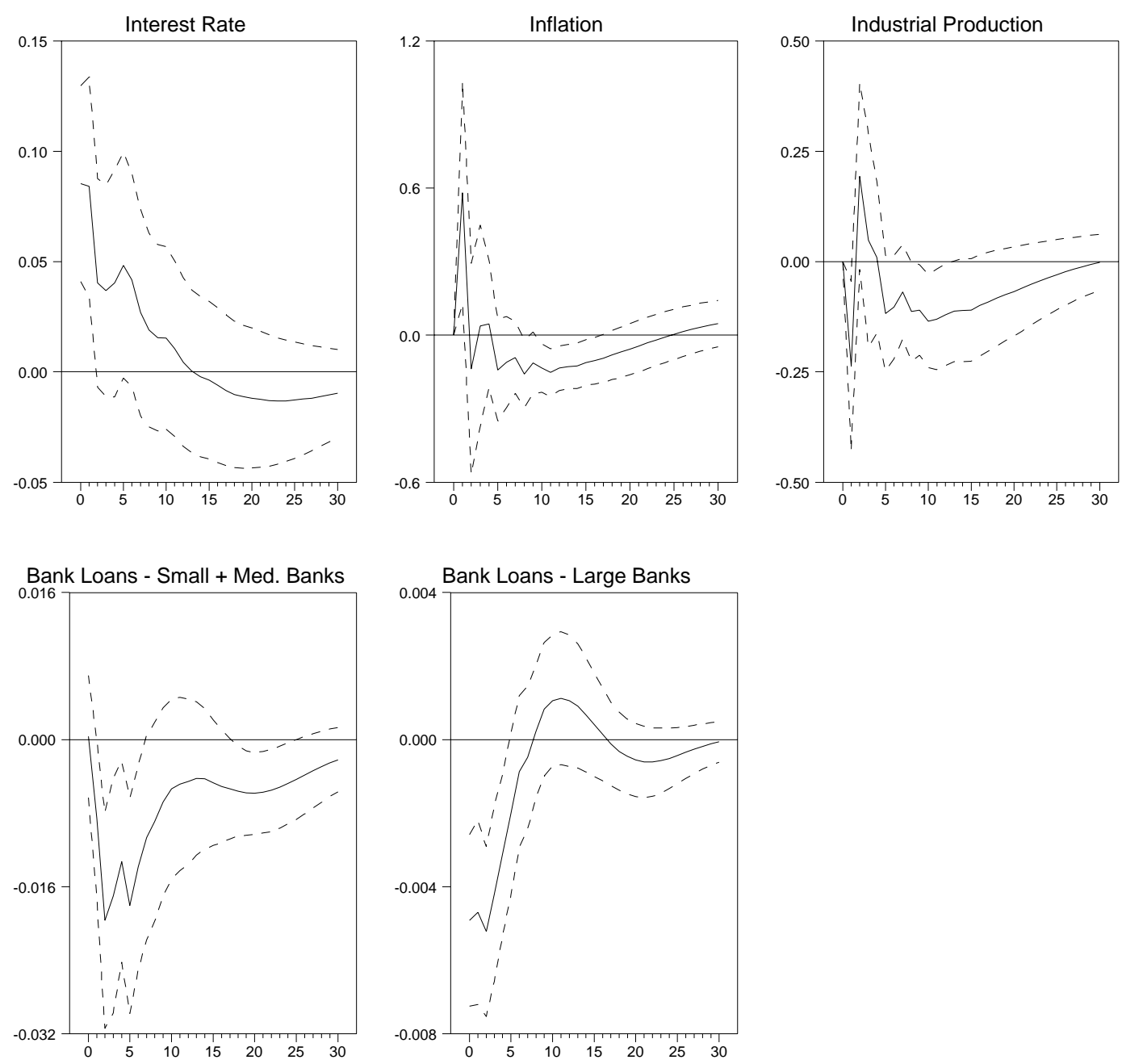


\section{A4: SENSITIVITY ANALYSIS: INCLUSION OF A LINEAR TREND IN THE REAL INTEREST RATE COINTEGRATING VECTOR}

Table A6: Test for overidentifying restrictions of the four cointegrating vectors, with and without a linear trend in the vector on real interest rates; interbank variables calculated with methodology (1), defined as ratios

(a) real interest rates trend-stationary

\begin{tabular}{|c|ccc|ccc|ccc|ccc|}
\hline & \multicolumn{3}{|c|}{ Interbank market } & \multicolumn{3}{c|}{ External } & \multicolumn{3}{c|}{ Internal } & \multicolumn{3}{c|}{ Abroad } \\
& small & med. & large & small & med. & large & small & med. & large & small & med. & large \\
\hline$\chi^{2}(4)$ & 4.92 & 4.60 & 1.79 & 4.09 & 3.43 & 1.69 & 5.08 & 2.02 & 2.02 & 2.25 & 1.89 & 2.31 \\
p-val. & 0.30 & 0.33 & 0.77 & 0.39 & 0.49 & 0.79 & 0.28 & 0.73 & 0.73 & 0.69 & 0.76 & 0.68 \\
\hline
\end{tabular}

(b) real interest rates stationary

\begin{tabular}{|c|ccc|ccc|ccc|ccc|}
\hline & \multicolumn{2}{|c|}{ Interbank market } & \multicolumn{3}{c|}{ External } & \multicolumn{3}{c|}{ Internal } & \multicolumn{3}{c|}{ Abroad } \\
& small & med. & large & small & med. & large & small & med. & large & small & med. & large \\
\hline$\chi^{2}(4)$ & 7.83 & 12.37 & 7.61 & 11.62 & 11.59 & 7.74 & 7.77 & 8.40 & 8.40 & 11.23 & 10.18 & 7.95 \\
p-val. & 0.10 & 0.01 & 0.11 & 0.02 & 0.02 & 0.10 & 0.10 & 0.08 & 0.08 & 0.02 & 0.04 & 0.09 \\
\hline
\end{tabular}

Figure A10: The effects of a monetary policy shock on interbank lending, sensitivity to the inclusion of a linear trend in the real interest rate cointegrating vector

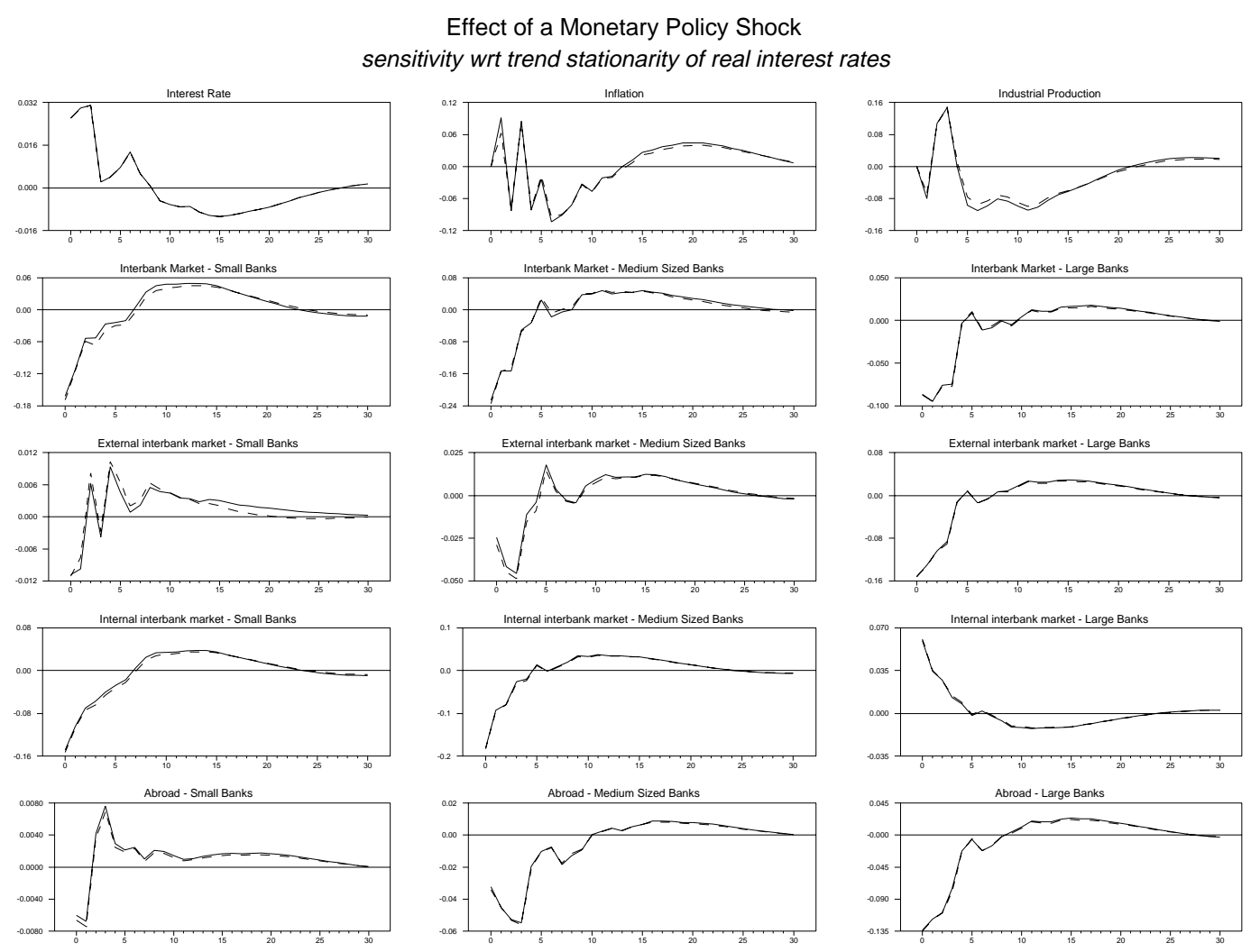




\section{European Central Bank Working Paper Series}

I "A global hazard index for the world foreign exchange markets" by V. Brousseau and F. Scacciavillani, May 1999.

2 "What does the single monetary policy do? A SVAR benchmark for the European Central Bank" by C. Monticelli and O. Tristani, May 1999.

3 "Fiscal policy effectiveness and neutrality results in a non-Ricardian world" by C. Detken, May 1999.

4 "From the ERM to the euro: new evidence on economic and policy convergence among EU countries" by I. Angeloni and L. Dedola, May 1999.

5 “Core inflation: a review of some conceptual issues" by M. Wynne, May 1999.

6 "The demand for M3 in the euro area" by G. Coenen and J.-L. Vega, September 1999.

7 "A cross-country comparison of market structures in European banking" by O. de Bandt and E. P. Davis, September 1999.

8 “Inflation zone targeting” by A. Orphanides and V. Wieland, October 1999.

9 "Asymptotic confidence bands for the estimated autocovariance and autocorrelation functions of vector autoregressive models" by G. Coenen, January 2000.

10 "On the effectiveness of sterilized foreign exchange intervention" by R. Fatum, February 2000.

II "Is the yield curve a useful information variable for the Eurosystem?" by J. M. Berk and P. van Bergeijk, February 2000.

12 “Indicator variables for optimal policy" by L. E. O. Svensson and M. Woodford, February 2000.

13 “Monetary policy with uncertain parameters" by U. Söderström, February 2000.

14 "Assessing nominal income rules for monetary policy with model and data uncertainty" by G. D. Rudebusch, February 2000.

15 "The quest for prosperity without inflation" by A. Orphanides, March 2000.

16 "Estimating the implied distribution of the future short term interest rate using the LongstaffSchwartz model" by P. Hördahl, March 2000.

17 "Alternative measures of the NAIRU in the euro area: estimates and assessment" by S. Fabiani and R. Mestre, March 2000.

18 "House prices and the macroeconomy in Europe: Results from a structural VAR analysis" by M. lacoviello, April 2000. 
19 “The euro and international capital markets" by C. Detken and P. Hartmann, April 2000.

20 "Convergence of fiscal policies in the euro area" by O. De Bandt and F. P. Mongelli, May 2000.

21 "Firm size and monetary policy transmission: evidence from German business survey data" by M. Ehrmann, May 2000.

22 "Regulating access to international large value payment systems" by C. Holthausen and T. Rønde, June 2000.

23 “Escaping Nash inflation” by In-Koo Cho and T. J. Sargent, June 2000.

24 "What horizon for price stability" by F. Smets, July 2000.

25 "Caution and conservatism in the making of monetary policy" by P. Schellekens, July 2000.

26 "Which kind of transparency? On the need for clarity in monetary policy-making" by B. Winkler, August 2000.

27 "This is what the US leading indicators lead" by M. Camacho and G. Perez-Quiros, August 2000.

28 "Learning, uncertainty and central bank activism in an economy with strategic interactions" by M. Ellison and N. Valla, August 2000.

29 "The sources of unemployment fluctuations: an empirical application to the Italian case" by S. Fabiani, A. Locarno, G. Oneto and P. Sestito, September 2000.

30 "A small estimated euro area model with rational expectations and nominal rigidities" by G. Coenen and V. Wieland, September 2000.

31 "The disappearing tax base: Is foreign direct investment eroding corporate income taxes?" by R. Gropp and K. Kostial, September 2000.

32 "Can indeterminacy explain the short-run non-neutrality of money?" by F. De Fiore, September 2000.

33 "The information content of M3 for future inflation" by C. Trecroci and J. L. Vega, October 2000.

34 "Capital market development, corporate governance and the credibility of exchange rate pegs” by O. Castrén and T. Takalo, October 2000.

35 “Systemic risk: A survey" by O. De Bandt and P. Hartmann, November 2000.

36 "Measuring core inflation in the euro area" by C. Morana, November 2000.

37 "Business fixed investment: Evidence of a financial accelerator in Europe" by P. Vermeulen, November 2000. 
38 "The optimal inflation tax when taxes are costly to collect" by F. De Fiore, November 2000.

39 "A money demand system for euro area M3" by C. Brand and N. Cassola, November 2000.

40 "Financial structure and the interest rate channel of ECB monetary policy" by B. Mojon, November 2000.

4I "Why adopt transparency? The publication of central bank forecasts" by P. M. Geraats, January 200I.

42 "An area-wide model (AWM) for the euro area" by G. Fagan, J. Henry and R. Mestre, January 200I.

43 "Sources of economic renewal: from the traditional firm to the knowledge firm" by D. R. Palenzuela, February 2001.

44 "The supply and demand for eurosystem deposits - The first 18 months" by U. Bindseil and F. Seitz, February 2001.

45 "Testing the Rank of the Hankel matrix: a statistical approach" by G. Camba-Mendez and G. Kapetanios, February 200I.

46 "A two-factor model of the German term structure of interest rates" by N. Cassola and J. B. Luís, February $200 \mathrm{I}$.

47 "Deposit insurance and moral hazard: does the counterfactual matter?" by R. Gropp and J. Vesala, February $200 \mathrm{I}$.

48 "Financial market integration in Europe: on the effects of EMU on stock markets" by M. Fratzscher, March 2001.

49 "Business cycle and monetary policy analysis in a structural sticky-price model of the euro area" by M. Casares, March 200I.

50 "Employment and productivity growth in service and manufacturing sectors in France, Germany and the US" by T. von Wachter, March 2001.

$5 I$ "The functional form of the demand for euro area MI" by L. Stracca, March 200 I.

52 "Are the effects of monetary policy in the euro area greater in recessions than in booms?" by G. Peersman and F. Smets, March 200 I.

53 "An evaluation of some measures of core inflation for the euro area" by J.-L. Vega and M. A. Wynne, April 200I.

54 “Assessment criteria for output gap estimates" by G. Camba-Méndez and D. R. Palenzuela, April 200I.

55 "Modelling the demand for loans to the private sector in the euro area" by A. Calza, G. Gartner and J. Sousa, April 200 I. 
56 "Stabilization policy in a two country model and the role of financial frictions" by E. Faia, April 2001.

57 “Model-based indicators of labour market rigidity" by S. Fabiani and D. Rodriguez-Palenzuela, April 2001.

58 "Business cycle asymmetries in stock returns: evidence from higher order moments and conditional densities" by G. Perez-Quiros and A. Timmermann, April 200 I.

59 “Uncertain potential output: implications for monetary policy” by M. Ehrmann and F. Smets, April 2001.

60 "A multi-country trend indicator for euro area inflation: computation and properties" by E. Angelini, J. Henry and R. Mestre, April 2001.

61 "Diffusion index-based inflation forecasts for the euro area" by E. Angelini, J. Henry and R. Mestre, April 200I.

62 "Spectral based methods to identify common trends and common cycles" by G. C. Mendez and G. Kapetanios, April 200I.

63 "Does money lead inflation in the euro area?" by S. N. Altimari, May 200 I.

64 "Exchange rate volatility and euro area imports" by R. Anderton and F. Skudelny, May 200 I.

65 "A system approach for measuring the euro area NAIRU” by S. Fabiani and R. Mestre, May 2001.

66 "Can short-term foreign exchange volatility be predicted by the Global Hazard Index?" by V. Brousseau and F. Scacciavillani, June 200I.

67 "The daily market for funds in Europe: Has something changed with the EMU?" by G. P. Quiros and H. R. Mendizabal, June 200I.

68 "The performance of forecast-based monetary policy rules under model uncertainty" by A. Levin, V. Wieland and J. C.Williams, July $200 \mathrm{I}$.

69 "The ECB monetary policy strategy and the money market" by V. Gaspar, G. Perez-Quiros and J. Sicilia, July $200 \mathrm{I}$.

70 "Central Bank forecasts of liquidity factors: Quality, publication and the control of the overnight rate” by U. Bindseil, July $200 \mathrm{I}$.

71 “Asset market linkages in crisis periods" by P. Hartmann, S. Straetmans and C. G. de Vries, July 2001.

72 "Bank concentration and retail interest rates" by S. Corvoisier and R. Gropp, July 200 I.

73 "Interbank lending and monetary policy transmission - evidence for Germany" by M. Ehrmann and A. Worms, July $200 \mathrm{I}$. 